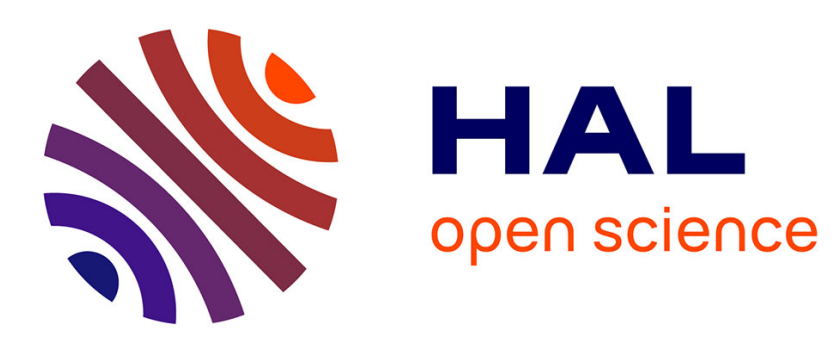

\title{
Altered feeding habits and strategies of a benthic forage fish () in chronically polluted tidal salt marshes
}

\author{
Daisuke Goto, William G. Wallace
}

\section{To cite this version:}

Daisuke Goto, William G. Wallace. Altered feeding habits and strategies of a benthic forage fish () in chronically polluted tidal salt marshes. Marine Environmental Research, 2011, 72 (1-2), pp.75. 10.1016/j.marenvres.2011.06.002 . hal-00720184

\section{HAL Id: hal-00720184 \\ https://hal.science/hal-00720184}

Submitted on 24 Jul 2012

HAL is a multi-disciplinary open access archive for the deposit and dissemination of scientific research documents, whether they are published or not. The documents may come from teaching and research institutions in France or abroad, or from public or private research centers.
L'archive ouverte pluridisciplinaire HAL, est destinée au dépôt et à la diffusion de documents scientifiques de niveau recherche, publiés ou non, émanant des établissements d'enseignement et de recherche français ou étrangers, des laboratoires publics ou privés. 


\section{Accepted Manuscript}

Title: Altered feeding habits and strategies of a benthic forage fish (Fundulus heteroclitus) in chronically polluted tidal salt marshes

Authors: Daisuke Goto, William G. Wallace

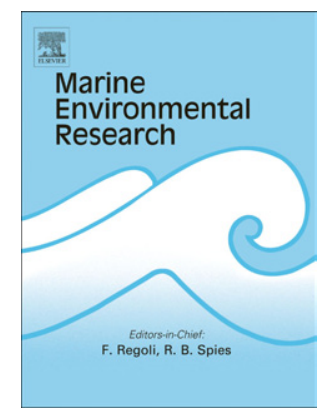

PII:

S0141-1136(11)00070-5

DOI:

10.1016/j.marenvres.2011.06.002

Reference: MERE 3531

To appear in: Marine Environmental Research

Received Date: 14 August 2009

Revised Date: 18 March 2011

Accepted Date: 8 June 2011

Please cite this article as: Goto, D., Wallace, W.G. Altered feeding habits and strategies of a benthic forage fish (Fundulus heteroclitus) in chronically polluted tidal salt marshes, Marine Environmental Research (2011), doi: 10.1016/j.marenvres.2011.06.002

This is a PDF file of an unedited manuscript that has been accepted for publication. As a service to our customers we are providing this early version of the manuscript. The manuscript will undergo copyediting, typesetting, and review of the resulting proof before it is published in its final form. Please note that during the production process errors may be discovered which could affect the content, and all legal disclaimers that apply to the journal pertain. 
1 Altered feeding habits and strategies of a benthic forage fish (Fundulus

2 heteroclitus) in chronically polluted tidal salt marshes

3

4 Daisuke Goto ${ }^{\mathrm{a}, \mathrm{c}, \mathrm{d}}$

5

6

7

8 Biology Program

9 Graduate School and University Center

10 City University of New York

11365 Fifth Avenue

12 New York, New York 10016, USA

13

$14{ }^{\mathrm{b}}$ Biology Department

15 College of Staten Island, 6S-310

16 City University of New York

172800 Victory Boulevard

18 Staten Island, New York 10314, USA

19

20

21

22

23

24

25

${ }^{\mathrm{c}}$ Corresponding author e-mail: dgoto@purdue.edu Phone: + 1 (765) 494-8086

${ }^{\mathrm{d}}$ Present address

Department of Forestry and Natural Resources

Purdue University 195 Marsteller Street

28 West Lafayette, IN 47907-2033 USA

29

30 
46 Abstract. Responses in feeding ecology of a benthic forage fish, mummichogs (Fundulus

47 heteroclitus), to altered prey resources were investigated in chronically polluted salt marshes (the

48 Arthur Kill-AK, New York, USA). The diet niche breadth of the AK populations of

49 mummichogs was significantly lower than that of the reference population, reflecting reduced

50 benthic macroinfaunal species diversity. Most of the AK populations also had two to three times

51 less food in their gut than the reference population. This disparity in gut fullness among the

52 populations appeared to be partly due to ingested prey size shifts; some of the AK populations

53 ingested fewer large prey than the reference population. Furthermore, benthic assemblages were

54 strongly associated with sediment-associated mercury; gut fullness of the AK populations also

55 significantly decreased with increasing mercury body burdens. These results indicate that chronic

56 pollution may have directly (chemical bioaccumulation) and indirectly (reduced prey

57 availability) altered the feeding ecology of mummichogs.

59 Keywords Trophic relationships; benthic environment; feeding strategy; pollution effects; diet

60 analysis; salt marshes; the Hudson River

61

62

63

64

65

66

67

68 


\section{Introduction}

70 Urban coastal habitats are often highly degraded due to a variety of human activities (e.g.,

71 accidental chemical discharges and dredging) (Able et al., 1998; Levin et al., 2001). Coastal

72 habitat degradation can alter food web structures and ecosystem functions including

73 biogeochemical cycling of materials from terrestrial, freshwater, and marine environments

74 (Levin et al., 2001). Among anthropogenic stressors, elevated levels of chemical pollutants can

75 have particularly persistent effects in aquatic organisms (Boesch et al., 2001). As the majority of

76 these anthropogenically introduced chemicals are bound to bottom sediments, benthic organisms

77 are especially vulnerable (Clements and Newman, 2002). Furthermore, since these benthic

78 organisms can also exhibit species-specific differential tolerance to a variety of chemical

79 pollutants, chemical pollution may ultimately alter the community structure and trophic

80 dynamics of benthic habitats (Clements and Newman, 2002).

81 In chronically degraded habitats, chemical pollutants can influence foraging behaviors (e.g.,

82 prey capture) of fish (Smith and Weis, 1997; Weis et al., 2001). Due to logistical difficulties,

83 however, it is often difficult to elucidate how altered foraging behaviors affect the feeding habits

84 of wild populations of fish (Clements and Newman, 2002; Weis et al., 2001). As both predator

85 and prey are often concurrently exposed to chemical pollutants in natural habitats, species-

86 specific differential sensitivities to these stressors can result in a variety of altered (often

87 unpredictable) predator-prey relationships (Livingston, 1984; Steimle et al., 1993).

88 Chemical pollutants can also indirectly restructure the biological assemblage, and these

89 indirect effects are often mediated through trophic relationships (Eby et al., 2005; Jeffree and

90 Williams, 1980). Deposit-feeding invertebrates, a common trophic group in coastal habitats, are

91 an important prey resource for fishes, shellfishes, and wading birds; anthropogenic impacts on 
92 these invertebrates can thus have cascading effects on their predators (Pinnegar et al., 2000).

93 Direct impacts of habitat degradation on marine benthic macroinfaunal assemblages have been

94 extensively investigated (Boesch, 1982). However, there have been relatively few attempts to

95 examine indirect effects of pollution, including the feeding habits of benthivorous predators in

96 marine and estuarine ecosystems (e.g., Hinz et al., 2005; Powers et al., 2005). As a result, there is

97 little mechanistic understanding of pollution-induced alterations in trophic structure and

98 ecosystem function (Livingston, 1984; Rose, 2000).

99 In the present study, the impacts of habitat degradation on benthic trophic interactions were

100 investigated by examining the feeding habits and strategies of mummichogs, Fundulus

101 heteroclitus (Pisces: Cyprinodontidae), in chemically polluted tidal salt marshes in New York,

102 USA. Mummichogs are among the most abundant and productive fishes in tidal creeks and salt

103 marshes in the northwest Atlantic coast (Meredith and Lotrich, 1979). Mummichogs thus play an

104 essential role in salt marsh food webs as an intermediate predator linking benthic invertebrates,

105 and piscivorous fishes and wading birds (Kneib, 1986). Within salt marshes, mummichogs also

106 exhibit a distinct ontogenetic shift in habitat use from vegetated intertidal pools and creeks

107 during larval and juvenile stages to primarily subtidal creeks as an adult (Kneib, 1997; Teo and

108 Able, 2003). Subtidal food resources may, however, not be sufficient or easily accessible to adult

109 mummichogs (Weisberg and Lotrich, 1982; Weisberg et al., 1981). In foraging for sufficient

110 prey resources, adult mummichogs thus regularly migrate from subtidal marshes to intertidal

111 marsh surface following tidal cycles (Kneib, 1997; Teo and Able, 2003).

112 Because of their ontogenetic tidal migration and strong site fidelity within salt marshes (Able

113 et al., 2006; McMahon et al., 2005), mummichogs are a key species in transporting secondary

114 production of salt marsh ecosystems in the northwest Atlantic coast (Kneib, 1997). A subtidal 
115 component of these salt marshes are frequently used as a feeding ground by juvenile and adult

116 migrant fish and shellfish species such as blue crab (Callinectus sapidus) and striped bass

117 (Morone saxatilis), which are potential predators of mummichogs (Nemerson and Able, 2003;

118 Peters and Schaaf, 1991). These migrant fishes and shellfishes consequently transport marsh

119 production incorporated by mummichogs to open coastal ecosystems (Kneib, 1997). Moreover,

120 through these trophic interrelationships, tidal migration of mummichogs from intertidal marsh

121 surface to subtidal creeks may also couple spatially semi-compartmentalized trophic components

122 (i.e., benthic invertebrates in intertidal marshes and migrant piscivores in subtidal creeks and

123 open bays) (Kneib, 1997; Weisberg et al., 1981). This cyprinodontid fish thus plays a critical role

124 in integrating and transporting a substantial portion of marsh productions to adjacent coastal

125 ecosystems (Kneib, 1997; Smith et al., 2000).

126 Relatively high tolerance to a variety of natural and anthropogenic stressors often allows

127 mummichogs to thrive even in highly polluted coastal habitats (Schulte, 2007; Weis, 2002). Due

128 to their opportunistic feeding habits, omnivorous predators such as mummichogs can also be an

129 integrative biological surrogate 'sampler' for the assessment of benthic habitat quality (e.g., Frid

130 and Hall, 1999; Link, 2004). Although mummichogs have frequently been used to assess

131 structural and functional recovery of restored salt marshes (e.g., Moy and Levin, 1991; Wozniak

132 et al., 2006), there are few studies assessing the trophic ecology of mummichogs in chemically

133 polluted habitats (e.g., Smith and Weis, 1997; Weis et al., 2001). Since mummichogs are an

134 important trophic link in urban coastal habitats, alterations in their relationships with prey (e.g.,

135 local elimination of benthic invertebrate species) may disrupt trophic coupling in urban tidal salt

136 marshes (Kneib, 2003). This decoupling of food chains within urban tidal salt marshes induced

137 by chemical pollution could disrupt secondary production and energy transport in coastal 
138 habitats. Understanding the effects of habitat degradation on the trophic ecology of mummichogs

139 is, therefore, highly relevant to the structural and functional assessments of urbanized salt

140 marshes (Moy and Levin, 1991).

142 2. Materials and methods

143 2.1. Study area

144 The study was conducted in the Arthur Kill-AK (part of the New York/New Jersey-NY/NJ

145 Harbor Estuary Complex), which is a tidal waterway located between northern New Jersey and

146 Staten Island, New York, connecting Newark Bay and Kill van Kull to the north, and Raritan

147 Bay, New York Harbor, and the Atlantic Ocean to the south (Fig. 1). Due to the proximity to

148 industrial facilities, petroleum refining facilities, heavy shipping traffic, and sewage treatment

149 plants, AK is one of the most severely polluted areas in the NY/NJ Harbor Estuary system

150 (Steinberg et al., 2004). A variety of anthropogenic disturbances have resulted in a considerable

151 loss of biodiversity in this region over the years (Steinberg et al., 2004). Among the

152 anthropogenic stressors, chemical pollutants released with industrial and municipal discharges

153 have been major contributors to the deterioration of trophic structure and ecosystem function in

154 this region (Bopp et al., 2006). Since tides enter from both ends of AK, this region is very poorly

155 flushed, resulting in enhanced entrapment and accumulation of pollutants in sediments (Bopp et

156 al., 2006). Due to potential toxicity and transference up food chains (Goto and Wallace, 2009),

157 chemical pollution is a major concern in this coastal ecosystem (Bain et al., 2007; Steinberg et 158 al., 2004).

159 Despite recent improvements in water quality of the NY/NJ Estuary Complex including AK 160 (Bopp et al., 2006; Steinberg et al., 2004), residual impacts of historic pollution can still be 
161 observed at many areas in the NY/NJ Harbor, including altered benthic assemblages (Bain et al.,

162 2007). As the NY/NJ Harbor Estuary also provides essential habitats for resident and migrant

163 aquatic as well as terrestrial species (Able et al., 1998; Steinberg et al., 2004), predators ingesting

164 benthic organisms are still at risk of exposure to these pollutants (Steinberg et al., 2004).

165

166

\subsection{Field sampling}

167 Sampling sites chosen for this study were four tributaries of AK; Richmond Creek, Main

168 Creek, Neck Creek, and Mill Creek, and one regional reference site (near Raritan Bay) external

169 to AK; Lemon Creek (Fig. 1). Neck Creek, which is located on the northwestern Staten Island,

$170 \mathrm{NY}$, is polluted with various chemicals due to its proximity to many oil refineries as well as

171 abandoned industrial facilities. Richmond Creek and Main Creek are tributaries of Fresh Kills

172 Complex, which is located on the western shore of Staten Island, and surrounded by the Fresh

173 Kills landfill. Mill Creek, on the southwestern shore of Staten Island, is located near the

174 confluence of AK and Raritan Bay and has been polluted from historic smelting activities.

175 Lemon Creek, which is located in the southeastern shore of Staten Island, is one of a few tidal

176 salt marshes that are relatively unaffected by human activities in the region.

177 Sampling of mummichogs was conducted in an intertidal area of each site during the summer

178 (July to September) of 2004 (two to three times per month). Mummichogs were collected using a

$1793.05 \times 1.22 \mathrm{~m}$-seine net with $6 \mathrm{~mm}$-polyester mesh or unbaited cylindrical minnow trap with 6

180 mm-mesh. The sampling was continued until a representative size of fish population at each site

181 ( $n=100$ to 200 ) were captured. To maximize sampling efficiency and minimize the digestion of

182 gut contents, fish were collected within approximately 60 to 90 minutes after daytime high tides,

183 which is the peak of mummichogs' daily foraging activity (Weisberg et al., 1981). When using 
184 minnow traps, fish were removed every 15 to 30 minutes to minimize the digestion of gut

185 contents (Beauchamp et al., 2007). Fish samples for diet analysis were immediately placed on ice

186 upon capture and then fixed with $10 \%$ formalin in the field (Bowen, 1996). Additional fish

187 samples for mercury $(\mathrm{Hg})$ analyses were also collected and transported on ice to laboratory.

188 Benthic macroinvertebrates were also collected to assess prey availability for mummichogs.

189 Macroinvertebrates were sampled by taking bulk surficial (top $\sim 5 \mathrm{~cm}$ ) sediments (one replicate

190 per a randomly chosen $100 \mathrm{~m}^{2}$ area) from the intertidal marsh at each study site, using a $15 \times 15$

$191 \mathrm{~cm}$-quadrat sampler $(n=5$ per site). Each sample was sieved through a $500 \mu \mathrm{m}$-mesh and fixed

192 with $10 \%$ formalin stained with Rose Bengal in a glass jar in the field, which was then

193 transported to the laboratory. Additional sediment samples were collected for analyses of trace

194 metals, grain size, and total organic carbon (TOC) content. Surface water temperature, $\mathrm{pH}$,

195 salinity, and dissolved oxygen (DO) were also measured within the proximity of each replicate

196 sample of benthic macroinvertebrates.

\subsection{Laboratory sample processing: Mummichogs}

199 In the laboratory, fish samples for diet analysis remained in formalin for at least one week

200 (Bowen, 1996). Samples from the different sampling dates were pooled for each site. Each fish

201 was first sexed, measured (total length $\pm 0.01 \mathrm{~mm}$ ), and weighed (wet weight $\pm 0.01 \mathrm{~g}$ ). Then,

202 the entire intestinal tract was excised and preserved individually in 70\% ethanol (Bowen, 1996).

203 Only the contents of the anterior 2/3 of intestines (equivalent to 'stomach') (Babkin and Bowie,

204 1928) were removed from the intestine, blotted dry, and placed on a pre-weighed petri dish to

205 weigh. All prey items were identified to the lowest practical taxonomic level under a dissecting 
206 microscope using available species keys in literature (Fauchald, 1977; Weiss, 1995; Merritt and 207 Cummins, 1996; Pollock, 1998).

208 The diet composition was quantified by frequency of occurrence, count, and weight of each 209 diet item (Bowen, 1996). To estimate the percentage contribution by weight for small prey (e.g., 210 meiofauna) and particulate matter (e.g., detritus) items, a modified version of the method by

211 Penczak (1985a) was used. Briefly, once identified, each diet item was separately squashed to a

212 uniform depth (assuming $1 \mathrm{~mm}^{3}=1 \mathrm{mg}$ wet weight) between glass slides (Penczak, 1985a).

213 Then, to increase accuracy, the area of each diet item was captured with a digital camera through

214 a dissecting microscope (Bowen, 1996) and measured $\left( \pm 0.001 \mathrm{~mm}^{2}\right)$ using a digital imaging

215 software (Motic Images Plus 2.0 ML). The total reconstructed weight estimates of diet items

216 were then compared with the actual weight of gut contents to ensure the accuracy of the method

217 (Bowen, 1996).

218 Fish samples for $\mathrm{Hg}$ analysis ( $n=\sim 30$ per site) were allowed to depurate gut contents for at 219 least 24 hours in filtered 15\% seawater and euthanized by an overdose of MS222. Then, fish 220 samples were homogenized with a Polytron tissue homogenizer (Kinematica, Inc., Switzerland)

221 in NANOpure ${ }^{\circledR}$ (reagent-grade) water. Homogenized samples were oven-dried $\left(\sim 60{ }^{\circ} \mathrm{C}\right)$ for 24 to 22248 hours. Oven dried samples were processed and analyzed for mercury, as described below.

224 2.4. Laboratory sample processing: Benthic macroinvertebrates

225 Benthic samples remained in formalin for at least seven days and then were preserved in $70 \%$

226 ethanol until species identification. Macroinvertebrates were identified to the lowest possible 227 taxonomic category (mostly to the species level) under a stereo microscope. Samples for each 
228 species were counted to estimate its abundance and subsequently dried in an oven at $60{ }^{\circ} \mathrm{C}$ to a

229 constant weight for approximately two hours to estimate its biomass.

\subsection{Laboratory sample processing: Sediments}

232 Sediment samples for grain size, TOC, and trace metal analyses were sieved through a 500

$233 \mu \mathrm{m}$-mesh to eliminate large objects (e.g., detritus) and macroinvertebrates. Subsamples of sieved

234 sediment samples $(<500 \mu \mathrm{m})$ were sieved further through a $73 \mu \mathrm{m}$-mesh and oven-dried (at 80

$235{ }^{\circ} \mathrm{C}$ for $\sim 48$ to 72 hours) to estimate $\%$ fine sediment particles $(<73 \mu \mathrm{m})$. The remaining sieved

236 sediment subsamples $(<500 \mu \mathrm{m})$ were homogenized, oven-dried (at $60{ }^{\circ} \mathrm{C}$ for $\sim 48-72$ hours),

237 and then divided for TOC and trace metal analyses. TOC was determined by combustion of

238 dried, ground sediments with a benchtop muffle furnace (Type 1400, Barnstread International) at

$239550{ }^{\circ} \mathrm{C}$ for six hours.

240 Oven-dried $\left(60^{\circ} \mathrm{C}\right)$ subsamples of sediments were divided further into two subsamples [one

241 for silver $(\mathrm{Ag})$, cadmium $(\mathrm{Cd})$, copper $(\mathrm{Cu})$, nickel $(\mathrm{Ni})$, lead $(\mathrm{Pb})$, and zinc $(\mathrm{Zn})$; one for $\mathrm{Hg}]$.

242 For $\mathrm{Ag}, \mathrm{Cd}, \mathrm{Cu}, \mathrm{Ni}, \mathrm{Pb}$, and $\mathrm{Zn}$, subsamples were digested under reflux with concentrated Trace

243 Metal Grade nitric acid overnight at room temperature $\left(\sim 20^{\circ} \mathrm{C}\right)$ and subsequently on a hotplate

$244\left(\sim 80^{\circ} \mathrm{C}\right)$ for $\sim 48$ to 72 hours. Once digested, samples were evaporated to dryness, re-suspended

245 in $2 \%$ nitric acid, and filtered. Metal concentrations in samples were analyzed with graphite

246 furnace atomic absorption spectrometer (for $\mathrm{Ag}, \mathrm{Cd}, \mathrm{Cu}, \mathrm{Ni}$, and $\mathrm{Pb}$ ) or flame atomic absorption

247 spectrophotometer (for Zn) (3100AAS, Perkin Elmer, Inc.).

248 For $\mathrm{Hg}$ analysis of sediments as well as mummichogs, dried subsamples were weighed and

249 transferred to an acid-washed 60 ml-BOD bottle. Samples were digested with a mixture (1:4 v/v)

250 of concentrated Trace Metal Grade nitric and sulfuric acids in a water bath $\left(\sim 60^{\circ} \mathrm{C}\right)$ for three 
251 hours and cooled in a refrigerator (US EPA, 1992). Samples were then oxidized with 5\%

252 potassium permanganate and 5\% potassium persulfate at room temperature overnight (US EPA,

253 1992). The digested samples were transferred into a 100 ml-volumetric flask, and $12 \%$ sodium

254 chloride-hydroxylamine chloride was added to reduce excess potassium permanganate (US EPA,

255 1992). Samples were then brought to final volume with NANOpure ${ }^{\circledR}$ (reagent-grade) water,

256 filtered, and analyzed with cold vapor atomic absorption spectrometer (Flow Injection Mercury

257 System, FIMS 100, Perkin Elmer, Inc.) using stannous chloride as a reducing reagent. Finally,

258 measured concentrations of sediment-associated $\mathrm{Ag}, \mathrm{Cd}, \mathrm{Cu}, \mathrm{Ni}, \mathrm{Pb}, \mathrm{Zn}$, and $\mathrm{Hg}$ were compared

259 with the Effects Range Median (ERM) levels proposed by Long and Morgan (1990), which

260 suggest the threshold levels of trace metals for adverse effects in marine and estuarine

261 organisms.

262

\section{2.6. Mummichog diet data analyses: Univariate measures}

264 Population-specific characteristics of the diet composition of mummichogs were first examined

265 using the following univariate measures; gut fullness index $(=100 \mathrm{x}$ weight of gut

266 contents/weight of fish) (Weisberg et al., 1981), prey species richness [Margalef's index, $d=(S-$

$2671) / \log _{\mathrm{e}} N ; S=$ the total number of prey species, $N=$ the total number of individuals] (Clifford and

268 Stephenson, 1975), diet niche breadth [Shannon-Wiener diversity index, $H^{\prime}=-\Sigma p_{i} \cdot \log _{\mathrm{e}}\left(p_{i}\right) ; p_{i}$

$269=$ the proportion of the abundance of the $i$ th prey species (Shannon and Weaver, 1949), as

270 suggested by Marshall and Elliott (1997)], and prey species evenness [Heip's evenness $=\left(\mathrm{e}^{H^{\prime}}-\right.$

271 1)/( $S-1)]$ (Heip, 1974). The representativeness of diet composition derived from the fish

272 samples examined was evaluated using a species-accumulation curve, which was based on a

273 cumulative number of species in the samples taken in a random order with 9999 permutations 
274 (Clarke and Gorley, 2006). The sample size was considered adequate if the species-accumulation 275 curves reached an asymptote.

276 The univariate measures were transformed using a logarithmic transformation, where

277 necessary. The normality of data was tested using Shapiro-Wilk's $W$ test. The homogeneity of

278 variance was tested using Levene's test. The statistical significance of differences in the

279 univariate indices among populations was tested using one-way analysis of variance (ANOVA),

280 which, if significant, was followed by Tukey's honestly significant difference (HSD) test. A

281 relationship between the body size of grass shrimp (a dominant prey item) ingested and fish total

282 length was tested using least squares regression, which was fitted with the Levenberg-Marquardt

283 algorithm. All univariate statistical analyses were performed using Statistica 7.1 (Statsoft, Inc,

284 USA).

285 Population-specific relative importance of each diet item ( $i$ ) was evaluated by the index of 286 relative importance $\left(I R I_{i}\right)$ (Bowen, 1996). In this study, the diet data were pooled into 14 diet 287 categories, according to their taxonomic relationships (mostly at the class level) for $I R I . I R I_{i}$ is 288 based on percentage contributions by frequency of occurrence $\left(\% F O_{i}\right)$, count $\left(\% N_{i}\right)$, and weight $289\left(\% W_{i}\right)\left[I R I_{i}=\% F O_{i} \times\left(\% N_{i}+\% W_{i}\right)\right]($ Cortés, 1997), which was adjusted to percentage for each 290 prey item $\left(\% I R I_{i}=100 \times I R I_{i} / \sum I R I_{i}\right)$, as suggested by Cortés (1997).

291 Population-specific prey selectivity was estimated using Chesson's index, $\alpha$, which is based on 292 the relative occurrence of the $i$ th prey item in the environment $\left(p_{i}\right)$ and in the gut content $\left(r_{i}\right)\left[\left(\alpha_{i}\right.\right.$ $\left.293=\left(r_{i} / p_{i}\right) / \sum\left(r_{i} / p_{i}\right) ; i=1, \ldots, \mathrm{m} ; 0 \leq \alpha_{i} \leq 1\right]$ (Chesson, 1978). Inference of prey selectivity is 294 based on a critical value for no or neutral selection that is defined as $\alpha_{\text {neutral }}=1 / \mathrm{m}$, where $\mathrm{m}=$ the 295 number of diet categories; if $\alpha_{i}>1 / \mathrm{m}$, prey $i$ is actively selected by a predator, while if $\alpha_{i}<1 / \mathrm{m}$, 296 prey $i$ is avoided by a predator (Chesson, 1978). In this study, $\alpha_{i}$ was calculated for eight $(\mathrm{m}=8$, 
297 i.e., $\alpha_{\text {neutral }}=0.125$ ) benthic macroinvertebrate taxonomic classes; Amphipoda, Isopoda,

298 Cirridedia, Polychaeta, Oligochaeta, Gastropoda, Bivalvia, and Insecta (aquatic insects only). In

299 calculating $\alpha_{i}$, the diet data were pooled for length classes, $60+\mathrm{mm}, 70+\mathrm{mm}$, and $80+\mathrm{mm}$ at

300 each site, as only these classes were reasonably represented at all sites.

301

\subsection{Mummichog diet data analyses: Multivariate analyses}

303 The statistical significance of differences in count and weight of diet composition among sites 304 and length classes was tested using two-way crossed analysis of similarity (ANOSIM) with 305 randomization permutation $(n=9999)$ at the significance level of $5 \%$, which, if significant, was 306 followed by pairwise comparisons (Clarke and Gorley, 2006). Two-way crossed analysis of 307 similarity percentages (SIMPER) was then used to identify dominant diet categories contributing 308 to dissimilarity among sites and length classes (Platell et al., 1998). In ANOSIM and SIMPER, 309 the diet data for length classes, $60+\mathrm{mm}, 70+\mathrm{mm}$, and $80+\mathrm{mm}$ were used. All analyses of 310 ANOSIM and SIMPER were performed using PRIMER v6.1.13 (PRIMER-E Ltd, Plymouth, $311 \mathrm{UK})$.

313 2.8. Statistical analyses of relationships between environmental variables and benthic

314 macroinfaunal prey assemblages

315 To examine relationships between benthic macroinfaunal prey assemblages and 316 physicochemical properties of the environment, canonical correspondence analysis (CCA) with 317 Hill's scaling on inter-species distances was used (ter Braak and Šmilauer, 2002). Prior to CCA, 318 all assemblage data were transformed using log-transformation $\left[\log _{\mathrm{e}}(\mathrm{x}+1)\right.$ for the abundance 319 data and $\log _{\mathrm{e}}(\mathrm{x}+0.001)$ for the biomass data] (McCune and Grace, 2002), while all the 
320 environmental variables were normalized (i.e., mean $=0$, standard deviation $=1)($ ter Braak and

321 Šmilauer, 2002). The statistical significance of all canonical axes was tested using a Monte Carlo

322 permutation test (999 unrestricted permutations under reduced model at $p<0.05)$ (ter Braak and

323 Šmilauer, 2002). Redundant environmental variables with Variance Inflation Factor (VIF) $>20$

324 (an indication of multicollinearity) were removed from further analyses (ter Braak and Šmilauer,

325 2002). The importance of environmental variables was assessed using intraset correlation with

326 the CCA axes (ter Braak, 1986). The relative importance of environmental variables after

327 removal of redundant variables was ranked using forward selection with Monte Carlo

328 permutation tests (999 unrestricted permutations under full model at $p<0.05$ ) (ter Braak and

329 Šmilauer, 2002). All CCAs were performed using CANOCO 4.5 (Microcomputer Power, New

330 York, USA).

\subsection{Statistical analyses of potential effects of $\mathrm{Hg}$ on mummichogs}

333 To assess potential effects of $\mathrm{Hg}$ on mummichogs, first, the statistical significance of

334 differences in $\mathrm{Hg}$ whole body burdens among populations was tested using one-way ANOVA,

335 which, if significant, was followed by Tukey's HSD test. Direct effects of $\mathrm{Hg}$ bioaccumulation

336 on the feeding habits of mummichogs were then examined by testing a relationship between $\mathrm{Hg}$

337 whole body burdens and gut fullness index using least squares regression.

340 3.1. Univariate comparisons of mummichog diet characteristics

341 Only a small fraction of the fish samples examined in this study had an empty gut (0\% to 6\%)

342 (Table 1). Prey species accumulation curves showed that the number of species found in guts had 
343 reached an asymptote at all sites, indicating the adequacy of sample size for the diet analysis.

344 There were significant differences in average gut fullness among the populations (ANOVA, $F_{4}$,

$345282=37, p<0.001)$, in which fish from Lemon Creek and Mill Creek had nearly two times more

346 food $\left(\sim 9.00 \mathrm{mg} \cdot\right.$ fish $\left.\mathrm{g}^{-1}\right)$ than those from Richmond Creek $\left(\sim 5.00 \mathrm{mg} \cdot\right.$ fish $\left.\mathrm{g}^{-1}\right)$ and three times

347 more than those from Main Creek and Neck Creek $\left(\sim 3.00 \mathrm{mg} \cdot f i s h \mathrm{~g}^{-1}\right)$ (Tukey HSD test, $p<$

3480.05 , Table 1). Although there were significant differences in prey species richness among

349 populations (ANOVA, $\left.F_{4,249}=2.6, p<0.05\right)$, the magnitude of the differences were small

350 (Table 1). Fish from Main Creek and Neck Creek had significantly lower prey species richness

351 than those from Lemon Creek (Tukey HSD test, $p<0.05$, Table 1). A similar trend was also

352 observed for diet niche breadth based on Shannon-Wiener index (ANOVA, $F_{4,251}=4.2, p<$

353 0.01), in which fish from Main Creek had a significantly lower niche breadth than those from

354 Lemon Creek (Tukey HSD test, $p<0.05$, Table 1). No significant difference was observed in

355 prey species evenness among the populations (ANOVA, $F_{4,251}=1.5, p=0.19$, Table 1 ).

356 In general, decapods (mainly Palaemonetes spp.) were the dominant (\%FO and \%W) and most

357 important (\%IRI) diet category observed in all populations, though there was some ontogenetic

358 variation, especially in the AK populations (Fig. 2a through e). Decapods generally became

359 increasingly important $(\% I R I=2.9 \%$ to $94 \%)$ with the total length of fish from all sites (Fig. 2a

360 through e). A moderate amount $(\% W=11 \%$ to $35 \%)$ of detritus was also frequently $(\% F O=$

$36130 \%$ to $100 \%$ ) found in the gut of mummichogs from all sites. At the AK sites (except for Mill

362 Creek), another important diet category was polychaetes (mostly Nereis spp.) (\%IRI=17\% to

$36324 \%$, Fig. 2c though e), which were frequently observed ( $\% F O=30 \%$ to $82 \%)$ and contributed

364 up to $\sim 40 \%$ by weight to the total gut contents. Gastropods (mostly Melampus bidentatus),

365 arachnids (mostly trombidiidae and ixodides), and insects (mostly diptera larvae) were frequently 
observed in fish from Lemon Creek (especially larger fish, $>70+\mathrm{mm} \mathrm{TL})(\% \mathrm{FO}=18 \%$ to $67 \%$

367 for gastropods, $17 \%$ to $62 \%$ for arachnids, and $33 \%$ to $61 \%$ for insects). Nematodes, though their

368 contribution to total gut content weight was negligible $(<1.0 \%)$, were also frequently observed

369 in the guts of fish from all sites $(\% F O=6 \%$ to $50 \%)$. Cirripedes (Balanus spp.) were frequently

370 observed in the guts of fish from Mill Creek, Richmond Creek, and Main Creek (\%FO =9\% to

$37150 \%$ ). Oligochaetes, bivalves, and teleosts were rarely found in the guts of mummichogs.

372 Prey selection by mummichogs based on the Chesson's index showed that only the Lemon

373 Creek and Mill Creek populations actively selected gastropods ( $\alpha=0.13$ to 0.31$)$ and insects $(\alpha=$

3740.23 to 0.43 ) (Fig. 3a and b). All populations of mummichogs consistently avoided bivalves and

375 oligochaetes (Fig. 3a through e). Although the selectivity of polychaetes by the AK populations

376 were higher than that by the Lemon Creek population, polychaetes were not actively selected $(\alpha$

$377<\sim 0.11)$ (Fig. 3a through e). The Neck Creek population actively selected only amphipods $(\alpha=$ 3780.59 to 0.73$)$ (Fig. 3e).

\subsection{Multivariate comparisons of mummichog diet compositions}

381 The diet compositions (both by weight and count) of mummichogs were significantly different 382 among the populations. Although the diet compositions were significantly different both among 383 sites (ANOSIM, $p<0.001$ by weight and count) and length classes (ANOSIM, $p<0.05$ by 384 weight and count), the global $R$ values for the among-site comparisons $(R=0.27$ by weight and $385 R=0.29$ by count) were considerably higher than those for the among-length class comparisons 386 ( $R=0.044$ by weight and $R=0.043$ by count). Thus, pairwise comparisons were done among 387 sites only. 
The post-hoc pairwise comparisons by weight among sites indicated that the diet composition of the Lemon Creek population was significantly different from those of the AK populations $(R$

$390=0.49$ to $0.71, p<0.05)$, with an exception of the Mill Creek population $(R=0.24, p>0.05)$.

391 The differences in diet composition among these populations were mainly due to fish from

392 Lemon Creek ingesting substantially more gastropods and less polychaetes (SIMPER, relative \%

393 contributions to dissimilarity $=22 \%$ to $25 \%$ by gastropods and $11 \%$ to $19 \%$ by polychaetes) than

394 those from Richmond Creek, Main Creek, and Neck Creek, as well as more decapods than those

395 from Main Creek (SIMPER, relative \% contributions to dissimilarity $=19 \%$ ).

396 The pairwise comparisons by count showed that the diet composition of fish from Lemon

397 Creek was significantly different from all the AK populations $(R=0.30$ to $0.78, p<0.05)$. A

398 significant difference was also found between Mill Creek and Richmond Creek $(R=0.38, p<$

399 0.05). The differences by count between Lemon Creek and the AK populations were due to the

400 ingestion of more insects and gastropods by fish from Lemon Creek than those from Mill Creek,

401 Main Creek, and Neck Creek (SIMPER, relative \% contributions to dissimilarity $=15 \%$ to $17 \%$

402 for insects and $12 \%$ to $17 \%$ for gastropods), whereas fish from Richmond Creek ingested fewer

403 gastropods and more polychaetes than those from Lemon Creek (SIMPER, relative \%

404 contributions to dissimilarity $=16 \%$ for gastropods and $14 \%$ for polychaetes).

\subsection{Relationships between body sizes of mummichogs and Palaemonetes spp.}

407 The body size of an individual Palaemonetes spp. (a dominant diet item by weight) ingested by

408 mummichogs was significantly correlated with the total length of mummichogs from all sites

409 (least squares regression, $p<0.05$, Fig. 4a through e). However, there was a substantial

410 difference in the length-specific maximum size of Palaemonetes spp. ingested by mummichogs 
411 among the populations. The gut contents of mummichogs from Main Creek and Neck Creek

412 contained mostly small Palaemonetes spp. $(<\sim 0.20 \mathrm{~g})$ and only a few individuals larger than

$413 \quad 0.40 \mathrm{~g}$ (Fig. 4d and 4e).

414

415 3.4. Relationships between environmental variables and benthic macroinfaunal prey

416 assemblages

417 Among trace metals measured, only mercury content in the sediment at the Arthur Kill (AK)

418 sites (varying from 0.80 to $2.46 \mu \mathrm{g} \cdot \mathrm{g}^{-1} \mathrm{dry}$ weight) was consistently above the ERM level,

419 whereas none of trace metals at Lemon Creek exceeded the ERM levels (Table 2). Canonical

420 correspondence analysis (CCA) showed significant relationships between environmental

421 variables and benthic macroinfaunal communities in both abundance $(F=11, p<0.001)$ and

422 biomass $(F=14, p<0.001)$. More than $70 \%$ of the total variances $(71 \%$ for abundance and $75 \%$

423 for biomass) in macroinfaunal communities were explained by the environmental variables

424 measured. The majority of the variances was explained by the first two statistically significant

425 canonical axes (Monte Carlo permutation test, $p<0.001$ ) for both abundance $(46 \%$ by the 1 st

426 axis $+11 \%$ by the 2 nd axis $=57 \%$ of the total variance $)$ and biomass data ( $51 \%$ by the 1 st axis +

$42713 \%$ by the 2 nd axis $=64 \%$ of the total variance) (Fig. 5 a and b). Stepwise forward selection

428 identified and ranked the environmental variables that significantly contributed to the total

429 explained variances in macroinfaunal compositions. For the abundance data, salinity (eigenvalue,

$430 \lambda=0.22 ; \%$ variance explained $=27 \%)$, mercury $(\lambda=0.14 ; 17 \%)$, surface dissolved oxygen $(\lambda=$

$4310.09 ; 11 \%)$, silver $(\lambda=0.09 ; 11 \%)$, and cadmium $(\lambda=0.05 ; 6.0 \%)$ significantly contributed to

432 the total variance (Fig. 5a). For the biomass data, salinity $(\lambda=0.36 ; 29 \%)$, mercury $(\lambda=0.23$; 
$43319 \%)$, cadmium $(\lambda=0.15 ; 12 \%)$, total organic carbon $(\lambda=0.12 ; 9.7 \%)$, and silver $(\lambda=0.06$;

$4344.9 \%$ ) significantly contributed to the total variance (Fig. 5b).

3.5. Relationships between mercury whole body burdens and gut fullness of mummichogs

437 Mean $\mathrm{Hg}$ whole body burdens in mummichogs were significantly different among the

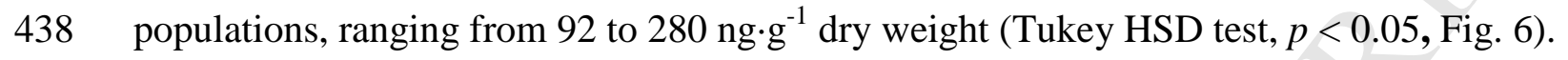

439 Increasing $\mathrm{Hg}$ whole body burdens in mummichogs were significantly correlated with

440 differences in gut fullness among the populations (least square regression, $p<0.001$, Fig. 7).

\section{4. Discussion}

443 Chronic habitat degradation has substantially altered biological assemblages of benthic habitats

444 in the Arthur Kill (AK) over the years (Crawford et al., 1994; Steinberg et al., 2004). In the

445 current study, benthic macroinfaunal assemblages in most of the AK salt marshes still exhibited

446 characteristics frequently observed in chronically polluted coastal benthic habitats, including

447 numerical dominance by a few small-bodied polychaete and oligochaete species (e.g.,

\section{$448 \quad$ Streblospio benedicti).}

449 Alterations in benthic macroinfaunal assemblages clearly resulted in markedly differences in

450 the feeding habits of mummichogs between the AK and reference (near Raritan Bay)

451 populations. The average relative gut fullness of mummichogs at the peak of their feeding

452 activity (i.e., daytime ebbing tides) was substantially lower at most of the AK sites (especially,

453 Main Creek and Neck Creek) than at the reference site (Lemon Creek). This disparity in gut

454 fullness among the populations appeared to be partly because of shifts in size of ingested prey;

455 the amount and frequency of consumption of large-bodied prey such as gastropods and decapods 
456 were much lower in most of the AK populations than in the reference population. Furthermore,

457 diet niche breadth and prey species richness of mummichogs were also lower at these northern

458 AK sites (Main Creek and Neck Creek), where the benthic macroinfaunal communities were also

459 especially impoverished (e.g., lower species diversity), than at the other AK sites. Only the

460 reference (Lemon Creek) population frequently ingested insects and gastropods, reflecting the

461 higher occurrence of these macroinvertebrates in the environment. The reduction or

462 disappearance of sensitive relatively large invertebrate groups such as many gastropods and

463 bivalves from benthic macroinfaunal communities is commonly observed in degraded salt

464 marshes (Warwick and Clarke, 1994; Weston, 1990). Although a large number of gastropods

465 were found at one of the AK sites, Mill Creek, a majority of them were Illynassa ventriretta,

466 which is far larger than the gape size of mummichogs (Vince et al., 1976; Werme, 1981). These

467 gastropods were thus not ingested by mummichogs. Meiofauna such as nematodes were fairly

468 frequently (6\% to 50\%) ingested by different sizes of fish from all sites. Because of their low

469 contributions by weight $(<1 \%)$, however, their functional importance to adult mummichogs may

470 be negligible (Penczak, 1985b).

471 Alterations in interspecific interactions in degraded habitats may benefit some pollution-

472 tolerant species in certain cases (Boesch, 1982; Steimle et al., 1993). For example, due to lack of

473 or reduced competition and predation, pollution-tolerant benthic invertebrates (e.g., opportunistic

474 deposit-feeding annelids) often dramatically increase in abundance at the initial stage of

475 recolonization following anthropogenic disturbances, which may in turn provide an increased

476 prey resource to their predators (Jeffree and Williams, 1980; Powers et al., 2005). The benefit of

477 an enhanced prey resource may, however, depend on the "preferred" prey type of predators

478 (Steimle, 1994; Steimle et al., 1993). In the present study, although the diet composition of the 
479 reference (Lemon Creek) population of mummichogs was significantly different from those of

480 the AK populations, there were only minor differences among the AK populations. Since many

481 dominant polychaete and oligochaete species at the AK sites were subsurface deposit-feeders,

482 which may not be easily accessible to mummichogs, differences in abundances of these deposit-

483 feeders among the sites may not have had measurable impacts on the diet compositions of

484 mummichogs in AK.

485 In general, despite their high abundance in urban tidal salt marshes, oligochaetes are rarely

486 found in the gut of mummichogs (Moy and Levin, 1991; Smith et al., 2000). Although it is

487 possible that rapid digestion of soft-bodied invertebrates (e.g., polychaetes and oligochaetes)

488 may influence their percentage contributions in the diet of mummichogs (Smith et al., 2000), the

489 present study indicated that enhanced abundances of oligochaetes in AK appear to have little or

490 no effect on the feeding habit of mummichogs. Werme (1981) has experimentally demonstrated

491 that mummichogs are much less efficient in foraging on sediment-dwelling prey than another

492 fundulid species, striped killifish (Fundulus majalis). Striped killifish often co-occurs with

493 mummichogs in tidal salt marshes in the northwest Atlantic coast, competing for prey resources

494 (Weisberg, 1986; Werme, 1981). Unlike striped killifish, however, mummichogs appear to

495 preferentially capture epibenthic prey, while striped killifish forage for potential prey items by

496 aggressively disturbing sediments (Sardá et al., 1998; Werme, 1981). As a result, these fundulid

497 species, despite a high degree of diet overlap, tend to have different 'preferences' in prey type

498 (Sardá et al., 1998; Weisberg, 1986); mummichogs generally 'prefer' relatively mobile prey such

499 as decapods and amphipods in intertidal marsh surface (Kneib and Stiven, 1978), while striped

500 killifish 'prefer' sedentary sediment-associated prey such as gastropods and bivalves (Brousseau 
501 et al., 2008). Further studies would, however, still require determining the importance of

502 subsurface deposit-feeders to the diet of mummichogs.

503 High abundances of some epibenthic decapods such as grass shrimp (Palaemonetes spp.) may

504 also have masked some indirect effects of altered prey resources on the feeding habits of

505 mummichogs in AK. Grass shrimp was relatively larger than other potential prey items available

506 and one of the most frequently found prey items at both the AK and reference sites. The body

507 size of individual grass shrimp ingested by mummichogs was, however, considerably smaller at

508 two of the northern AK sites, Main Creek and Neck Creek, than at the other sites. These site-

509 specific relationships between mummichogs and grass shrimp observed in the current study may

510 have been due to altered feeding behaviors induced by chemical pollutants such as mercury

511 (Smith and Weis, 1997; Weis et al., 2001).

512 Canonical correspondence analysis in the current study indicated that a relatively large

513 proportion of among-site variance of benthic macroinfaunal communities (in both abundance and

514 biomass) was strongly associated with increasing concentrations of sediment-associated mercury

515 in the AK sites. Furthermore, a decrease in gut fullness of the AK (particularly, Main Creek and

516 Neck Creek) populations was also significantly correlated with increasing Hg whole body

517 burdens in mummichogs. Similarly, Weis et al. (2001) have also shown that mummichogs from

518 severely chemically polluted coastal habitats in New York and New Jersey (including AK)

519 ingested considerably fewer grass shrimp than those from the reference sites. Experimental

520 studies have demonstrated that anthropogenically introduced toxic chemicals such as mercury

521 can impair mummichogs' ability to capture epibenthic decapods (Smith and Weis, 1997; Weis et

522 al., 2001). These altered feeding behaviors ultimately reduce the ingestion of decapods by

523 mummichogs (Smith and Weis, 1997; Weis et al., 2001). In addition to prey availability, 
524 chemical pollutants may thus also directly influence the feeding habits of fish by altering their

525 feeding behaviors in urban coastal habitats.

526 Like many other fish species, mummichogs are a visual (Weisberg et al., 1981) and size-

527 selective predator (Kneib, 1986), influencing prey abundance and distribution in tidal salt

528 marshes (Kneib and Stiven., 1982; Vince et al., 1976). Smith and Weis (1997) have

529 demonstrated that chronic exposure to chemical pollutants such as mercury can also alter size-

530 selective feeding of mummichogs. In addition to direct effects of anthropogenic stressors, altered

531 size-selective predation pressure may also lead to a shift in size structure of benthic

532 macroinvertebrate assemblages (Kneib and Stiven., 1982; Vince et al., 1976). Santiago-Bass et

533 al. (2001) have shown that the body size of the AK (Piles Creek, New Jersey) population of grass

534 shrimp is considerably larger than that of a reference (Tuckerton, New Jersey) population,

535 suggesting that grass shrimp may not only benefit from the reduced predator pressure from

536 mummichogs, but also be more tolerant to chemical pollution than mummichogs (Weis et al.,

537 2000). These species-specific differential responses to chemical pollutants suggest that altered

538 feeding behaviors of predators can also have top-down (reverse) cascading effects on their prey

539 (i.e., reduced predation pressure) in severely polluted benthic habitats (Santiago-Bass et al.,

540 2001; Weis et al., 2000).

541 Both altered feeding behaviors (e.g., reduced prey capture efficacy) and prey availability (e.g.,

542 disappearance of large-bodied prey) may also influence ontogenetic diet shifts of mummichogs

543 in urban benthic habitats. In general, large adult mummichogs ( $>\sim 70 \mathrm{~mm}$ TL) feed on decapods

544 such as fiddler crab (Uca spp.) and grass shrimp (Palaemonetes spp.) (Kneib and Stiven, 1978),

545 whereas small adults and juveniles $(<\sim 40 \mathrm{~mm}$ TL) feed on small crustaceans such as copepods

546 (Able et al., 2008; Smith et al., 2000). In the current study, the amount of large prey such as 
547 decapods such as grass shrimp generally increased with the body size of mummichogs, whereas

548 the amount of other prey items (especially polychaetes) decreased at most sites. Mummichogs

549 from the northern AK sites (Main Creek and Neck Creek) that ingested only small shrimp,

550 however, mainly substituted with an increased ingestion of other prey including amphipods and

551 polychaetes until they reached the largest size group (> $80 \mathrm{~mm}$ TL). In fact, the Neck Creek

552 population continued to actively select amphipods even when they reached the largest size group.

553 Increased abundance and biomass of polychaetes are commonly observed in degraded marine

554 benthic habitats (Warwick and Clarke, 1993; Weston, 1990), including the AK tidal salt marshes.

555 In the current study, higher relative proportion (by weight) of polychaetes was more frequently

556 observed in the diets of fish from the northern AK sites (Main Creek, Richmond Creek, and

557 Neck Creek) than those from the southern AK (Mill Creek) and the reference (Lemon Creek)

558 sites. The most frequently observed polychaete species in the present study was Nereis spp.,

559 which was also one of the most abundant polychaete species (particularly, N. acuminata) found

560 in the AK benthic macroinfaunal communities. Moreover, Nereis spp. were relatively larger than

561 other polychaete species found in AK; they may thus have been more conspicuous to

562 mummichogs than other abundant, but smaller polychaete species such as Hobsonia florida and

563 Streblospio benedicti.

564 Previous studies have suggested that an increased ingestion of detritus may indicate pollution

565 impacts on the feeding habits of mummichogs in urban salt marshes with impoverished prey

566 resources (Smith and Weis, 1997; Weis et al., 2001). In the current study, however, there was no

567 consistent difference in the amount of detritus ingested by mummichogs among the populations.

568 A frequent occurrence ( $\sim 31 \%$ to $100 \%$ ) of detritus with an average of $\sim 20 \%$ (by weight) of total

569 gut contents was observed in all populations of mummichogs. This frequent ingestion of detritus 
570 is not uncommon for many benthivorous predators such as mummichogs (Gerking, 1994; Moy

571 and Levin, 1991). Mummichogs are also unlikely to use detritus as a primary food source for

572 their growth or metabolism (Prinslow et al., 1974; White et al., 1986). Furthermore, in the

573 current study, a large amount of detritus was often found in the guts of mummichogs with

574 sediment-dwelling invertebrates such as polychaetes, but not with highly mobile epibenthic prey

575 such as grass shrimp. The occurrence of detritus may thus have been due to an accidental

576 ingestion (Kneib and Stiven, 1978; Penczak, 1985b). In habitats with limited prey resource such

577 as urbanized tidal salt marshes, however, mummichogs may continue to unintentionally ingest

578 detritus in search for sediment-dwelling prey as a short-term strategy (Weisberg and Lotrich,

579 1986). Altered prey availability in the environment may thus indirectly influence the amount of

580 detritus ingested by mummichogs.

581 Macroalgae (e.g., Ulva spp.) were also frequently found in the gut contents of mummichogs in

582 the present study. The frequency of occurrence was slightly higher in the reference (Lemon

583 Creek) and Mill Creek populations than the other populations, whereas the relative proportion

584 (by weight) was much larger in the AK populations than the reference population. Unlike

585 detritus, the ingestion of macroalgae by mummichogs may not be accidental (Fell et al., 1998),

586 though mummichogs often feed on small crustaceans and insects that aggregate around

587 macroalgae (Werme, 1981). The amount of plant material in the gut of some benthivorous fishes

588 in coastal habitats including mummichogs is known to increase with their body size (Able et al.,

589 2008; Smith et al., 2000). In general, larvae and juveniles of these benthivorous fishes in coastal

590 habitats are often primarily carnivorous, feeding mostly on meiofauna and macroinfaunal larvae,

591 while adults become more omnivorous, ingesting a progressively increasing amount of plant

592 material as they grow (Kneib and Stiven, 1978; Smith et al., 2000). Although the morphology of 
593 their digestive tract suggests that mummichogs are not well suited for herbivorous feeding habits

594 (Weisberg, 1986; Werme, 1981), Moerland (1985) has experimentally demonstrated that there is

595 a temperature-dependent cellulase activity in the digestive tract of mummichogs. It is thus

596 possible that mummichogs may partially substitute an insufficient invertebrate prey supply with

597 macroalgae, when necessary.

598 Non-random perturbations such as chemical pollution to trophic structures may provide a

599 unique opportunity to elucidate intricate trophic interactions in aquatic ecosystems (Fleeger et

600 al., 2003; Raffaelli, 2005). The results based on the Chesson's selectivity index in the current

601 study revealed the highly flexible nature of the overall feeding strategy of mummichogs, mostly

602 corresponding to general patterns in benthic macroinfaunal communities, as suggested by

603 previous studies (e.g., Moy and Levin, 1991). A large amount of decapods (mostly,

604 Palaemonetes spp.) was frequently observed in the gut of adult mummichogs, due most likely to

605 their high abundance (personal observation) and relatively large body size. However,

606 mummichogs did show some preference to amphipods, isopods, and aquatic insects, as well as

607 avoidance of oligochaetes and bivalves, regardless of changes in their availabilities in the

608 environment. For example, although the Main Creek population ingested more polychaetes than

609 the reference population, this was not resulted from active selection, but from an increased

610 abundance of polychaetes and possibly a reduced ingestion (most likely reduced prey-capture

611 efficiency) of preferred prey (e.g., decapods). These results suggest that even at degraded

612 habitats with impoverished prey resources, mummichogs still exhibit some prey preference as

613 well as their trophic adaptability.

614

\section{5. Conclusions}


616 The present study showed that chronic chemical pollution appeared to have directly (through

617 chemical bioaccumulation) and indirectly (through reduced benthic prey availability) altered

618 feeding habits and strategies of mummichogs in highly urbanized tidal salt marshes of the Arthur

619 Kill (AK). Since benthic macroinvertebrates are highly responsive to altered environmental

620 conditions in urban coastal habitats, the direct trophic relationship with these invertebrates may

621 have integrated overall anthropogenic impacts on benthic habitats. Furthermore, as chemical

622 pollutants such as mercury can be transferred through food chains and accumulate in predators

623 (Goto and Wallace 2009), the diet habits of the AK populations of mummichogs may also have

624 been influenced by chemically induced alterations in feeding behaviors.

625 The predominant prey of adult mummichogs in the present study, grass shrimp, are also among

626 the most productive macroinvertebrate species in tidal salt marshes in the northwest Atlantic

627 coast and known to feed not only on plant material, but also on a variety of benthic meiofauna

628 and macroinfauna (Gregg and Fleeger, 1998). Due to their intimate association with the cycling

629 of materials and energy in coastal ecosystems, partial trophic decoupling between mummichogs

630 and grass shrimp observed in some of the AK sites could thus disrupt not only energy transfer to

631 mummichogs, but also ecosystem functioning in these highly urbanized salt marshes.

632 Altered prey resources often induce functional responses in predators such as food

633 consumption and growth rates, including mummichogs (Goto and Wallace, 2010), which could

634 also influence trophically mediated ecosystem processes (e.g., energy flow and nutrient cycling)

635 (Eby et al., 2005; Peterson et al., 2000). The importance of integrity of trophic structure to

636 ecosystem functioning is widely recognized (Clements and Newman, 2002). Empirical and

637 experimental studies have demonstrated a close association between biodiversity and ecosystem

638 functioning; low-biodiversity ecosystems (e.g., urban tidal salt marshes) are likely to have low 
639 buffering capacity toward further anthropogenic disturbances (Woodward et al., 2005).

640 Urbanized coastal ecosystems with simplified trophic structure are likely to be at a vulnerable

641 state, potentially facing food chain collapse from a loss of a member of the food web (Clements

642 and Newman, 2002). Furthermore, tidal salt marshes are among the most productive

643 environments (Levin et al., 2001), supporting adjacent coastal ecosystems (Deegan et al., 2000).

644 The spatial movement of marsh production toward open coastal habitats is intimately associated

645 with the trophic interactions between resident and migrant nekton ("trophic relay") in salt

646 marshes (Kneib, 1997). As a key resident species in urban salt marshes, monitoring the feeding

647 ecology of mummichogs (e.g., trophic relationships with grass shrimp) is, therefore, critical in

648 understanding the structural and functional responses to restorations of chronically degraded

649 coastal habitats.

\section{Acknowledgements}

652 This project was supported by New York Sea Grant (project number, R/CTP-39) funded under 653 award \# NA16RG1645 from the National Sea Grant College Program of the U.S. Department of 654 Commerce's National Oceanic and Atmospheric Administration, to the Research Foundation of 655 State University of New York on behalf of New York Sea Grant. The statements, findings, 656 conclusions, views, and recommendations are those of the author(s) and do not necessarily 657 reflect the views of any of those organizations. Additional funding was also provided by the 658 Graduate Center, the City University of New York under the Doctoral Student Research Grant

659 Program. We greatly appreciate field and laboratory assistance provided by M. Perez and D.

660 Seebaugh and useful comments provided by R. R. Veit, J. W. Rachlin, J. R. Waldman, P. Weis, 661 and an anonymous reviewer. 
References

664

665

666

667

668

669

670

671

672

673

674

675

676

677

678

679

680

681

682

683

684

685

686

687

688

689

690

691

692

693

694

695

696

697

698

699

700

701

702

703

704
Able, K.W., Duffy-Anderson, J.T., 2006. Impacts of piers on juvenile fishes in the lower Hudson River. In: J.S. Levinton, J.R. Waldman (Eds), The Hudson River Estuary, Cambridge University Press, New York, NY, pp. 428-440.

Able, K.W., Grothues, T.M., Hagan, S.M., Kimball, M.E., Nemerson, D.M., Taghon, G.L., 2008. Long-term response of fishes and other fauna to restoration of former salt hay farms: multiple measures of restoration success. Rev. Fish Biol. Fish. 18, 65-97.

Able, K.W., Hagan, S.M., Brown, S.A., 2006. Habitat use, movement, and growth of young-ofthe-year Fundulus spp. in southern New Jersey salt marshes: comparisons based on tag/recapture. J. Exp. Mar. Biol. Ecol. 335, 177-187.

Able, K.W., Manderson, J.P., Studholme, A.L., 1998. The distribution of shallow water juvenile fishes in an urban estuary: the effects of manmade structures in the lower Hudson River. Estuaries 21, 731-744.

Babkin, B.P., Bowie, D.J., 1928. The digestive system and its function in Fundulus heteroclitus. Biol. Bull. 54, 254-277.

Bain, M., Lodge, J., Suszkowski, D.J., Botkin, D., Brash, A., Craft, C., Diaz, R., Farley, k., Gelb, Y., Levinton, J.S., Matuszeski, W., Steimle, F., Wilber, P., 2007. Target ecosystem characteristics for the Hudson Raritan Estuary: technical guidance for developing a comprehensive ecosystem restoration plan. A report to the Port Authority of NY/NJ. In, Hudson River Foundation, New York, NY, pp. 106.

Beauchamp, D.A., Wahl, D.H., Johnson, B.M., 2007. Predator-prey interactions. In: C.S. Guy, M.L. Brown (Eds), Analysis and interpretation of freshwater fisheries data, American Fisheries Society, Bethesda, Maryland, pp. 765-842.

Boesch, D.F., 1982. Ecosystem consequences of alterations of benthic community structure and function in the New York Bight region. In: G.F. Mayer (Ed), Ecological stress in the New York Bight: Science and management, Estuarine Research Federation, Columbia, SC, USA, pp. 543-568.

Boesch, D.F., Burroughs, R.H., Baker, J.E., Mason, R.P., Rowe, C.L., Siefert., R.L., 2001. Marine pollution in the United States. In, Pew Oceans Commission, Arlington, Virginia.

Bopp, R.F., Chillrud, S.N., Shuster, E., Simpson, H.J., 2006. Contaminant chronologies from Hudson River sedimentary records. In: J.S. Levinton, J.R. Waldman (Eds), The Hudson River Estuary, Cambridge University Press, New York, pp. 383-397.

Bowen, S.H., 1996. Quantitative description of the diet. In: B.R. Murphy, D.W. Willis, (Eds), Fisheries techniques, American Fisheries Society, Bethesda, Maryland, pp. 513-529.

Brousseau, D.J., Murphy, A.E., Enriquez, N.P., Gibbons, K., 2008. Foraging by two estuarine fishes, Fundulus heteroclitus and Fundulus majalis, on juvenile asian shore crabs (Hemigrapsus sanguineus) in Western Long Island Sound. Estuar. Coast. 31, 144-151.

Chesson, J., 1978. Measuring preference in selective predation. Ecology 59, 211-215.

Clarke, K.R., Gorley, R.N., 2006. PRIMER v6: User manual/tutorial. PRIMER-E Ltd, Plymouth. Clements, W.H., Newman, M.C., 2002. Community ecotoxicology. John Wiley and Sons. Clifford, H.T., Stephenson, W., 1975. An introduction to numerical classification. Academic Press, New York. 
Cortés, E., 1997. A critical review of methods of studying fish feeding based on analysis of stomach contents: application to elasmobranch fishes. Can. J. Fish. Aquat. Sci. 54, 726738.

Crawford, D.W., Bonnevie, N.L., Gillis, C.A., Wenning, R.J., 1994. Historical changes in the ecological health of the Newark Bay Estuary, New Jersey. Ecotoxicol. Environ. Safety $29,276-303$.

Deegan, L.A., Hughes, J.E., Rountree, R.A., 2000. Salt marsh ecosystem support of marine transient species. In: M.P. Weinstein, D.A. Kreeger (Eds), Concepts and controversies in tidal marsh ecology, Kluwer Academic Publishing, The Netherlands, pp. 333-365.

Eby, L.A., Crowder, L.B., McClellan, C.M., Peterson, C.H., Powers, M.J., 2005. Habitat degradation from intermittent hypoxia: impacts on demersal fishes. Mar. Ecol. Prog. Ser. 291, 249-262.

Fauchald, K., 1977. The polychaete worms: definitions and keys to the orders, families and genera. Natural History Museum of Los Angeles, Los Angeles, CA.

Fell, P.E., Weissbach, S.P., Jones, D.A., Fallon, M.A., Zeppieri, J.A., Faison, E.K., Lennon, K.A., Newberry, K.J., Reddington, L.K., 1998. Does invasion of oligohaline tidal marshes by reed grass, Phragmites australis (Cav.) Trin. ex Steud., affect the availability of prey resources for the mummichog, Fundulus heteroclitus L.? J. Exp. Mar. Biol. Ecol. 222, 59-77.

Fleeger, J.W., Carman, K.R., Nisbet, R.M., 2003. Indirect effects of contaminants in aquatic ecosystems. Sci. Total Environ. 317, 207-233.

Frid, C.L.J., Hall, S.J., 1999. Inferring changes in North Sea benthos from fish stomach analysis. Mar. Ecol. Prog. Ser. 184, 183-188.

Gerking, S.D., 1994. Feeding ecology of fish. Academic Press, London.

Goto, D., Wallace, W.G., 2009. Influences of prey- and predator- dependent processes on cadmium and methylmercury trophic transfer to mummichogs (Fundulus heteroclitus). Can. J. Fish. Aquat. Sci. 66, 836-846.

Goto, D., Wallace, W.G., 2010. Bioenergetic responses of a benthic forage fish (Fundulus heteroclitus) to habitat degradation and altered prey community in polluted salt marshes.

Can. J. Fish. Aquat. Sci. 67, 1566-1584.

Gregg, C.S., Fleeger, J.W., 1998. Grass shrimp Palaemonetes pugio predation on sediment- and stem-dwelling meiofauna: Field and laboratory experiments. Mar. Ecol. Prog. Ser. 175, $77-86$.

Heip, C., 1974. A new index measuring evenness. J. Mar. Biol. Assoc. UK 48, 555-557.

Hinz, H., Kröncke, I., Ehrich, S., 2005. The feeding strategy of dab Limanda limanda in the southern North Sea: linking stomach contents to prey availability in the environment. J. Fish Biol. 67, 125-145.

Jeffree, R.A., Williams, N.J., 1980. Mining pollution and the diet of the purple-striped gudgeon Mogurnda mogurnda Richardson (Eleotridae) in the Finniss River, Northern Territory, Australia. Ecol. Monogr 50, 457-485.

Kneib, R.T., 1986. The role of Fundulus heteroclitus in salt marsh trophic dynamics. Am. Zool. 26, 259-269.

Kneib, R.T., 1997. The role of tidal marshes in the ecology of estuarine nekton. Oceanogr. Mar. Biol. Annu. Rev. 35, 163-220.

Kneib, R.T., 2003. Bioenergetic and landscape considerations for scaling expectations of nekton production from intertidal marshes. Mar. Ecol. Prog. Ser. 264, 279-296. 
Kneib, R.T., Stiven, A.E., 1978. Growth, reproduction and feeding of Fundulus heteroclitus (L.) on a North Carolina salt marsh. J. Exp. Mar. Biol. Ecol 31, 121-140.

Kneib, R.T., Stiven., A.E., 1982. Benthic invertebrate responses to size and density manipulations of the common mummichog, Fundulus heteroclitus, in an intertidal salt marsh. Ecology 63, 1518-1532.

Levin, L.A., Boesch, D.F., Covich, A., Dahm, C., Erséus, C., Ewel, K.C., Kneib, R.T., Moldenke, A., Palmer, M.A., Snelgrove, P., Strayer, D., Weslawski, J.M., 2001. The function of marine critical transition zones and the importance of sediment biodiversity. Ecosystems 4, 430-451.

Link, J.S., 2004. Using fish stomachs as samplers of the benthos: integrating long-term and broad scales. Mar. Ecol. Prog. Ser. 269, 265-275.

Livingston, R.J., 1984. Trophic response of fishes to habitat variability in coastal seagrass systems. Ecology 65, 1258-1275.

Long, E.R., Morgan, L.G., 1990. The potential for biological effects of sediment-sorbed contaminants tested in the National Status and Trends Program. In, NOAA Technical Memorandum NOS OMA 52, NOAA, Seattle, WA.

Marshall, S., Elliott, M., 1997. A comparison of univariate and multivariate numerical and graphical techniques for determining inter- and intraspecific feeding relationships in estuarine fish. J. Fish Biol. 51, 526-545.

McCune, B., Grace, J.B., 2002. Analysis of ecological communities. MjM Software Design, Gleneden Beach, Oregon. 300 pp.

McMahon, K.W., Johnson, B.J., Ambrose, W.G., 2005. Diet and movement of the killifish, Fundulus heteroclitus, in a Maine salt marsh assessed using gut contents and stable isotope analyses. Estuaries 28, 966-973.

Meredith, W.H., Lotrich, V.A., 1979. Production dynamics of a tidal creek population of Fundulus heteroclitus (Linnaeus). Estuar. Coast. Shelf Sci. 8, 99-118.

Merritt, R.W., Cummins, K.W., 1996. An introduction to the aquatic insects of North America. Kendall Hunt Pub Co, Dubuque, IA.

Moerland, T.S., 1985. Cellulase activity in natural and temperature acclimated populations of Fundulus heteroclitus. Mar. Ecol. Prog. Ser. 26, 305-308.

Moy, L.D., Levin, L.A., 1991. Are Spartina marshes a replaceable resource? A functional approach to evaluation of marsh creation efforts. Estuaries 14, 1-16.

Nemerson, D.M., Able, K.W., 2003. Spatial and temporal patterns in the distribution and feeding habits of Morone saxatilis in marsh creeks of Delaware Bay, USA. Fish. Manag. Ecol. 10, 337-348.

Penczak, T., 1985a. A method of estimating total food consumed by fish populations. Hydrobiologia 123, 241-244.

Penczak, T., 1985b. Trophic ecology and fecundity of Fundulus heteroclitus in Chezzetcook Inlet, Nova Scotia. Mar. Biol. 89, 235-243.

Peters, D.S., Schaaf, W.E., 1991. Empirical model of the trophic basis for fishery yield in coastal waters of the eastern USA. Trans. Am. Fish. Soc. 120, 459-473.

Peterson, C.H., Summerson, H.C., Thomson, E., Lenihan, H.S., Grabowski, J., Manning, L., Micheli, F., Johnson, G., 2000. Synthesis of linkages between benthic and fish communities as a key to protecting essential fish habitat. Bull. Mar. Sci. 66, 759-774. 
Pinnegar, J.K., Polunin, N.V.C., Francour, P., Chemello, R., Harmelin-Vivien, M., Hereu, B., Milazzo, M., Zabala, M., 2000. Trophic cascades in benthic marine ecosystems: lessons for fisheries and protected-area management. Environ. Conserv. 27, 179-200.

Platell, M.E., Potter, C., Clarke, K.R., 1998. Do the habitats, mouth morphology and diets of the mullids Upeneichthys stotti and $U$. lineatus in coastal waters of south-western Australia differ? J. Fish Biol. 52, 398-418.

Pollock, L.W., 1998. A practical guide to the marine animals of northeastern North America. Rutgers University Press, New Brunswick, New Jersey.

Powers, S.P., Peterson, C.H., Christian, R.R., Sullivan, E., Powers, M.J., Bishop, M.J., Buzzelli, C.P., 2005. Effects of eutrophication on bottom habitat and prey resources of demersal fishes. Mar. Ecol. Prog. Ser. 302, 233-243.

Prinslow, T.E., Valiela, I., Teal., J.M., 1974. The effect of detritus and ration size on the growth of Fundulus heteroclitus (L.). J. Exp. Mar. Biol. Ecol. 16, 1-10.

Raffaelli, D.G., 2005. Tracing perturbation effects in food webs: The potential and limitation of. experimental approaches. In: P.C. de Ruiter, V. Wolters, J.C. Moore (Eds), Dynamic food webs: multispecies assemblages, ecosystem development, and environmental change, Academic Press, San Diego.

Rose, K.A., 2000. Why are quantitative relationships between environmental quality and fish populations so elusive? Ecol. Appl. 10, 367-385.

Santiago-Bass, C., Bhan, S., Smith, G.M., Weis, J.S., 2001. Some factors affecting size distribution and density of grass shrimp (Palaemonetes pugio) populations in two New Jersey estuaries. Hydrobiologia 450, 231-241

Sardá, R., Foreman, K., Werme, C.E., Valiela, I., 1998. The impact of epifaunal predation on the structure of macroinfaunal invertebrate communities of tidal saltmarsh creeks. Estuar. Coast. Shelf Sci. 46, 657-669.

Schulte, P.M., 2007. Responses to environmental stressors in an estuarine fish: interacting stressors and the impacts of local adaptation. Journal of Thermal Biology 32, 152-161.

Shannon, C.E., Weaver, W. (eds.), 1949. The mathematical theory of communication. University of Illinois Press, Urbana, IL.

Smith, G.M., Weis, J.S., 1997. Predator-prey relationships in mummichogs (Fundulus heteroclitus (L.)): effects of living in a polluted environment. J. Exp. Mar. Biol. Ecol 209, 75-87.

Smith, K.J., Taghon, G.L., Able, K.W., 2000. Trophic linkages in marshes: ontogenetic changes in diet for young-of-the-year mummichog, Fundulus heteroclitus. In: M.P. Weinstein, D.A. Kreeger (Eds), Concepts and controversies in tidal marsh ecology, Kluwer Publishing, The Netherland, pp. 121-237.

Steimle, F.W., Jeffress, D., Fromm, S.A., Reid, R.N., Vitaliano, J.J., Frame, A., 1993. Predatorprey relationships of winter flounder, Pleuronectes americanus, in the New York Bight apex. Fish. Bull. 92, 608-619.

Steimle, F.W., 1994. Sewage sludge disposal and winter flounder, red hake, and American lobster feeding in the New York Bight. Mar. Environ. Res. 37, 233-256.

Steinberg, N., Suszkowski, D.J., Clark, L., Way, J., 2004. Health of the harbor: the first comprehensive look at the state of the NY/NJ Harbor Estuary. A report to the NY/NJ Harbor Estuary Program. In, Hudson River Foundation, New York, NY, pp. 82.

Teo, S.L.H., Able, K.W., 2003. Habitat use and movement of the mummichog (Fundulus heteroclitus) in a restored salt marsh. Estuaries 26, 720-730. 
841

842

843

844

845

846

847

848

849

850

851

852

853

854

855

856

857

858

859

860

861

862

863

864

865

866

867

868

869

870

871

872

873

874

875

876

877

878

879

880

881

882

883

884

885

886

ter Braak, C.J.F., 1986. Canonical correspondence analysis: a new eigenvector technique for multivariate direct gradient analysis. Ecology 67, 1167-1179.

ter Braak, C.J.F., Šmilauer, P., 2002. CANOCO reference manual and CanoDraw for Windows user's guide: software for canonical community ordination (version 4.5). Microcomputer Power, Ithaca, NY, USA. 500 pp.

US EPA. 1992. Determination of mercury in tissues by cold vapor atomic absorption spectrometry. pp. 307-321 Methods of the determination of metals in environmental samples, Environmental Monitoring Systems Laboratory, US Environmental Protection Agency, Cincinnati, Ohio.

Vince, S., Valiela, I., Backus, N., Teal, J.M., 1976. Predation by the salt marsh killifish Fundulus heteroclitus (L.) in relation to prey size and habitat structure: consequences for prey distribution and abundance. J. Exp. Mar. Biol. Ecol. 23, 255-266.

Warwick, R.M., Clarke, K.R., 1993. Comparing the severity of disturbance: a meta-analysis of marine macrobenthic community data. Mar. Ecol. Prog. Ser. 92, 221-231.

Warwick, R.M., Clarke, K.R., 1994. Relearning the ABC: taxonomic changes and abundance/biomass relationships in disturbed benthic communities. Mar. Biol. 118, 739 744.

Weis, J.S., 2002. Tolerance to environmental contaminants in the mummichog, Fundulus heteroclitus. Hum. Ecol. Risk Assess. 8, 933-953.

Weis, J.S., 2005. Diet and food web support of the white perch, Morone americana, in the Hackensack Meadowlands of New Jersey. Environ. Biol. Fish. 74, 109-113.

Weis, J.S., Samson, J., Zhou, T., Skurnick, J., Weis, P., 2001. Prey capture ability of mummichogs (Fundulus heteroclitus) as a behavioral biomarker for contaminants in estuarine systems. Can. J. Fish. Aquat. Sci. 58, 1442-1452.

Weis, J.S., Smith, G., Santiago-Bass, C., 2000. Predator/prey interactions: a link between the individual level and both higher and lower level effects of toxicants in aquatic ecosystems. J. Aquat. Ecosys. Stress Recov. 7, 145-153.

Weisberg, S.B., 1986. Competition and coexistence among four estuarine species of Fundulus. Am. Zool. 26, 249-257.

Weisberg, S.B., Lotrich, V.A., 1982. The importance of an infrequently flooded intertidal marsh surface as an energy source for the mummichog Fundulus heteroclitus: an experimental approach. Mar. Biol. 66, 307-310.

Weisberg, S.B., Lotrich, V.A., 1986. Food limitation of a Delaware salt marsh population of the mummichog, Fundulus heteroclitus (L.). Oecologia 68, 168-173.

Weisberg, S.B., Whalen, R., Lotrich, V.A., 1981. Tidal and diurnal influence on food consumption of a salt marsh killifish Fundulus heteroclitus. Mar. Biol. 61, 243-246.

Weiss, H.M., 1995. Marine animals of southern New England and New York: identification keys to common nearshore and shallow water macrofauna. State Geological and Natural History Survey of Connecticut Department of Environmental Protection, Hartford, Connecticut.

Werme, C.E., 1981. Resource partitioning in a salt marsh fish community. PhD dissertation, Boston University, Boston, MA.

Weston, D.P., 1990. Quantitative examination of macrobenthic community changes along an organic enrichment gradient. Mar. Ecol. Prog. Ser. 61, 233-244.

White, D.S., D'Avanzo, C., Valiela, I., Lasta, C., Pascual, M., 1986. The relationship of diet to growth and ammonium excretion in salt marsh fish. Environ. Biol. Fish. 16, 105-112. 
Woodward, G., Emmerson, M.E., Olesen, J.M., Valido, A., Warren, P.H., Ebenman, B., 2005. Body-size determinants of pattern and process in ecological networks. In: P.C. de Ruiter, V. Wolters, J.C. Moore (Eds), Dynamic food webs: multispecies assemblages, ecosystem development, and environmental change, Academic Press, San Diego, pp. 179-197. Wozniak, A.S., Roman, C.T., Wainright, S.C., McKinney, R.A., James-Pirri, M.-J., 2006. Monitoring food web changes in tide-restored salt marshes: a carbon stable isotope approach. Estuaries 29, 568-578.

\section{Figure captions}

Fig. 1. Map of study sites in the Arthur Kill (Mill Creek, Richmond Creek, Main Creek, and Neck Creek) and Raritan Bay (Lemon Creek), New York, USA.

Fig. 2. Contributions by index of relative importance (IRI) $(\%)$ of diet categories (Decapoda, Amphipoda, Isopoda, Cirridedia, Polychaeta, Oligochaeta, Nematoda, Gastropoda, Bivalvia, Arachnida, Insecta, zooplankton, Osteichthyes, Alga, and detritus) to the length class (mm, TL)specific diet compositions of mummichogs from (a) Lemon Creek, (b) Mill Creek, (c) Richmond Creek, (d) Main Creek, and (e) Neck Creek.

Fig. 3. Chesson's index prey selectivity by $60+$ (black bars), $70+$ (gray bars), and $80+$ (dark gray bars) mm-size classes of mummichogs from (a) Lemon Creek, (b) Mill Creek, (c) Richmond Creek, (d) Main Creek, and (e) Neck Creek. Dotted horizontal lines indicate a critical value for no or neutral selection $\left(\alpha_{\text {neutral }}=0.125\right)$.

Fig. 4. Relationships between the total length $(\mathrm{mm})$ of mummichogs and body size (g, wet weight) of Palaemonetes spp. in the gut contents of mummichogs from (a) Lemon Creek, (b) Mill Creek, (c) Richmond Creek, (d) Main Creek, and (e) Neck Creek. Solid lines indicate a best-fit regression.

Fig. 5. Biplot representation (Axes 1 and 2) of canonical correspondence analysis (CCA) on (a) abundance and (b) biomass of benthic macroinvertebrates in relation to environmental variables at study sites. Environmental variables are represented by arrows; species are represented by open triangles. The length of arrows indicates the relative importance of environmental variables. Arrows pointing in the same direction indicate positive correlation, while arrows pointing in the opposite direction indicate negative correlation. $\mathrm{DO}=$ dissolved oxygen. $\mathrm{TOC}=$ total organic carbon. Eteone $=$ Eteone lactea, Hobsonia $=$ Hobsonia florida, Streblospio $=$ Streblospio benedicti, Edotea $=$ Edotea triloba, Macoma = Macoma balthica, Mya = Mya arenaria, Cyathura = Cyathura polita, Gammarus = Gammarus mucronatus, Ilyanassa = Ilyanassa trivittata, Glycinde $=$ Glycinde salitaria, Balanus $=$ Balanus improvises, Prionospio $=$ Prionospio sp., Pectinaria $=$ Pectinaria gouldii, Corophium $=$ Corophium volutator, Uca $=U c a$ pugnax, Ophelia $=$ Ophelia denticulate, Palaemonetes $=$ Palaemonetes larvae, and Spio $=$ Spio setosa.

Fig. 6. Mean mercury whole body burdens (ng. $\mathrm{g}^{-1}$, dry weight) in mummichogs from the study sites. Different letters indicate statistically significant difference among the populations (oneway ANOVA followed by Tukey's HSD test). 
933 Fig. 7. A relationship between mean mercury whole body burdens (ng. $\mathrm{g}^{-1}$, dry weight) and gut 934 fullness $\left(\mathrm{mg} \cdot \mathrm{g}^{-1}\right.$, wet weight) of mummichogs from the study sites. A solid line indicates a best935 fit regression. 
Table 1. Fish sample characteristics and mean values $( \pm$ SE) of indices (gut fullness, prey species richness, prey species diversity, and prey species evenness) for the gut contents of mummichogs from the study sites.

\begin{tabular}{|c|c|c|c|c|c|}
\hline & \multicolumn{5}{|c|}{ Study sites } \\
\hline & Lemon Creek & Mill Creek & Richmond Creek & Main Creek & Neck Creek \\
\hline Sample size & $n=44$ & $n=44$ & $n=56$ & $n=73$ & $n=68$ \\
\hline Size range $(\mathrm{TL}, \mathrm{mm})$ & $43-88$ & $59-100$ & $60-99$ & $41-81$ & $45-89$ \\
\hline (g, wet weight) & $1.1-10.0$ & $3.1-16.0$ & $2.7-15.0$ & $41.0-81.0$ & $0.80-7.6$ \\
\hline Empty stomach (\%) & 0.0 & 0.0 & 1.6 & 5.6 & 5.9 \\
\hline \multicolumn{6}{|l|}{ Diet indices } \\
\hline Gut fullness & $9.0 \pm 0.5 \mathrm{a}$ & $8.4 \pm 0.5 \mathrm{a}$ & $5.0 \pm 0.3 b$ & $2.9 \pm 0.3 c$ & $3.3 \pm 0.3 \mathrm{c}$ \\
\hline Margalef's & $1.9 \pm 0.10 \mathrm{a}$ & $1.7 \pm 0.06 \mathrm{ab}$ & $1.8 \pm 0.06 \mathrm{ab}$ & $1.6 \pm 0.05 b$ & $1.6 \pm 0.06 b$ \\
\hline Shannon-Wiener & $1.2 \pm 0.10 \mathrm{a}$ & $1.0 \pm 0.05 \mathrm{ab}$ & $1.0 \pm 0.06 \mathrm{ab}$ & $0.8 \pm 0.05 b$ & $0.8 \pm 0.06 \mathrm{~b}$ \\
\hline Heip's & $0.84 \pm 0.03$ & $0.92 \pm 0.03$ & $0.93 \pm 0.02$ & $0.92 \pm 0.03$ & $0.88 \pm 0.03$ \\
\hline
\end{tabular}

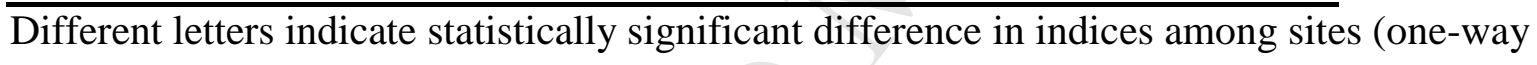
ANOVA followed by Tukey's HSD test). 
Table 2. Mean values of physicochemical environmental variables of the study sites during the summer of 2004. Metal concentrations above the ERM levels are indicated in bold

\begin{tabular}{|c|c|c|c|c|c|c|}
\hline \multirow[b]{2}{*}{ Environmental variables } & \multicolumn{5}{|c|}{ Study sites } & \multirow[b]{2}{*}{ Neck Creek } \\
\hline & $\mathrm{ERM}^{\mathrm{a}}$ & Lemon Creek & Mill Creek & Richmond Creek & Main Creek & \\
\hline Temperature $\left({ }^{\circ} \mathrm{C}\right)$ & & 25.2 & 28.3 & 29.6 & 26.0 & 31.6 \\
\hline Dissolved oxygen $\left(\mathrm{mg} \cdot \mathrm{l}^{-1}\right)$ & & 6.13 & 6.53 & 3.07 & 2.80 & 16.1 \\
\hline Salinity & & 6.3 & 14.7 & 5.0 & 6.0 & 14.0 \\
\hline $\mathrm{pH}$ & & 7.68 & 7.26 & 7.88 & 7.93 & 8.70 \\
\hline Fine sediment particles (\%) & & 33.5 & 74.7 & 60 & 17.5 & 59.5 \\
\hline Total organic carbon (\%) & & 5.95 & 4.92 & 2.38 & 5.43 & 12.5 \\
\hline \multicolumn{7}{|l|}{ Trace metals $\left(\mu \mathrm{g} \cdot \mathrm{g}^{-1}\right.$, dry } \\
\hline \multicolumn{7}{|l|}{ weight) } \\
\hline $\mathrm{Ag}$ & 3.7 & 0.83 & 1.38 & 0.78 & 1.59 & 1.37 \\
\hline $\mathrm{Cd}$ & 9.6 & 1.20 & 2.88 & 1.58 & 2.90 & 1.08 \\
\hline $\mathrm{Cu}$ & 270 & 125 & 912 & 99.7 & 216 & 153 \\
\hline $\mathrm{Hg}$ & 0.71 & 0.28 & 0.98 & 0.80 & 1.86 & 2.46 \\
\hline $\mathrm{Ni}$ & 51.6 & 27.9 & 36.5 & 34.0 & 70.3 & 49.0 \\
\hline $\mathrm{Pb}$ & 218 & 83.9 & 656 & 91.9 & 171 & 215 \\
\hline $\mathrm{Zn}$ & 410 & 220 & 1190 & 289 & 411 & 339 \\
\hline
\end{tabular}




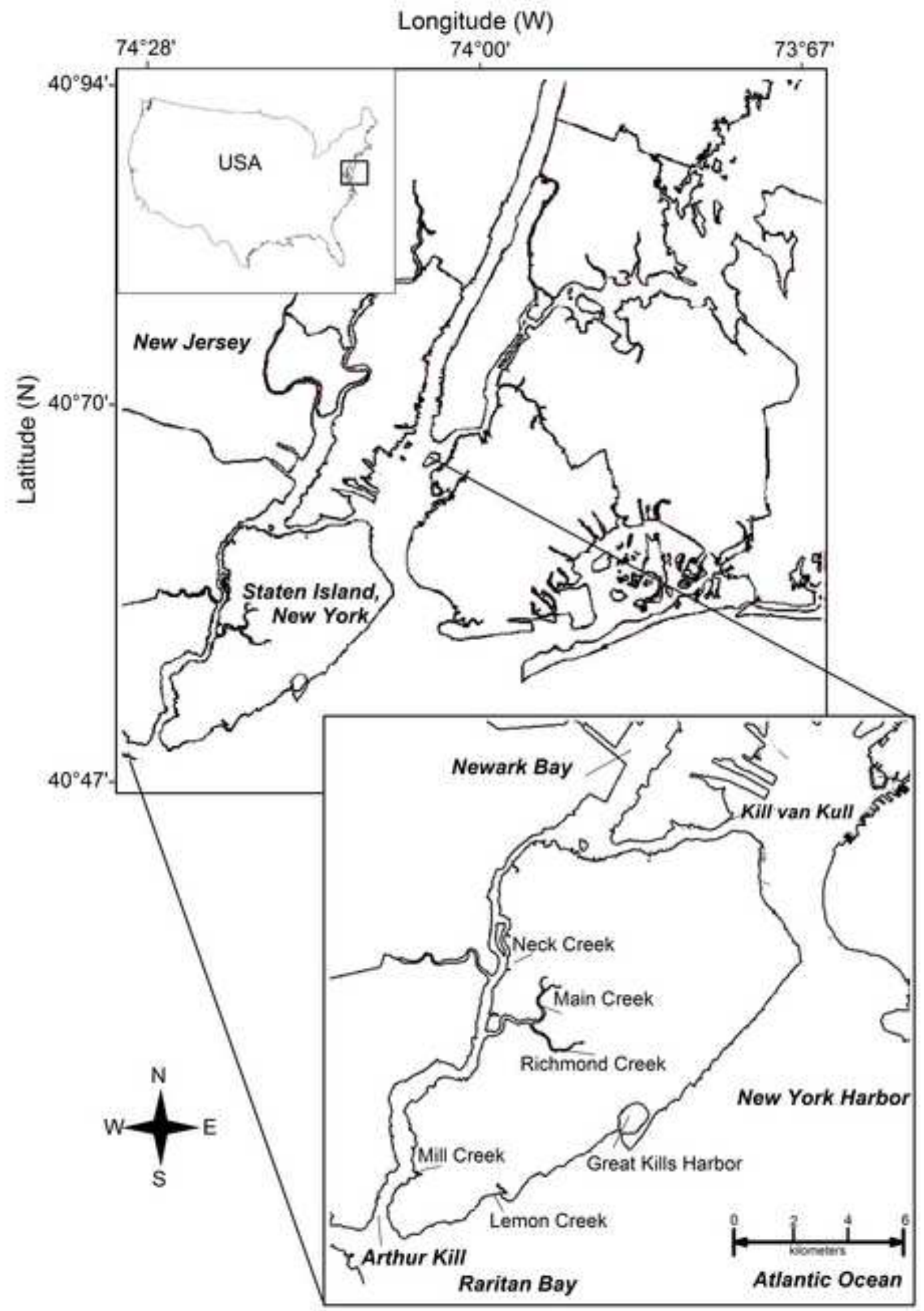




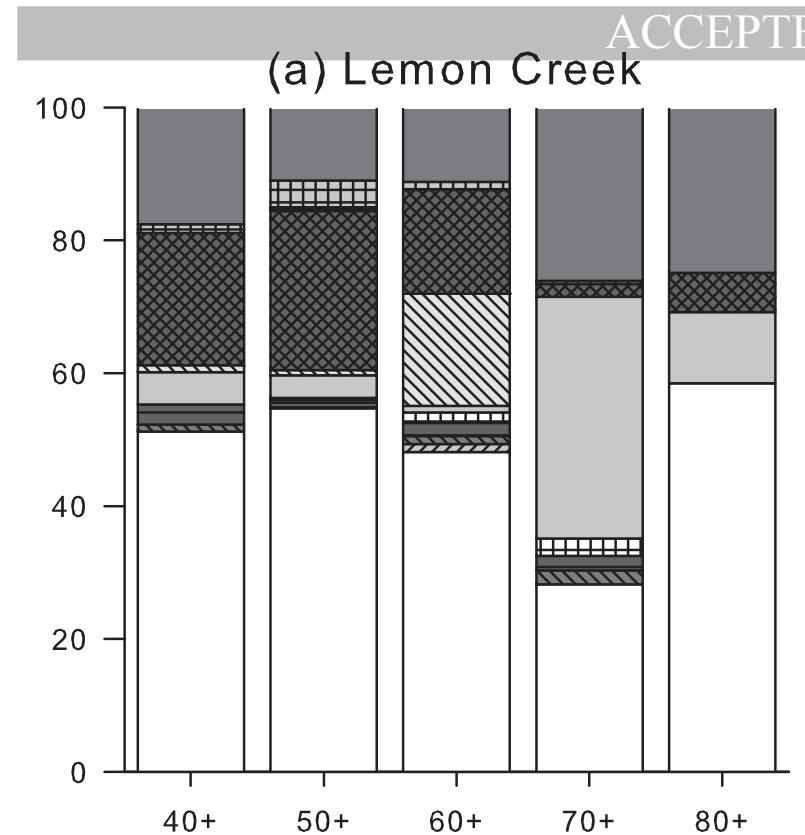

(d) Main Creek

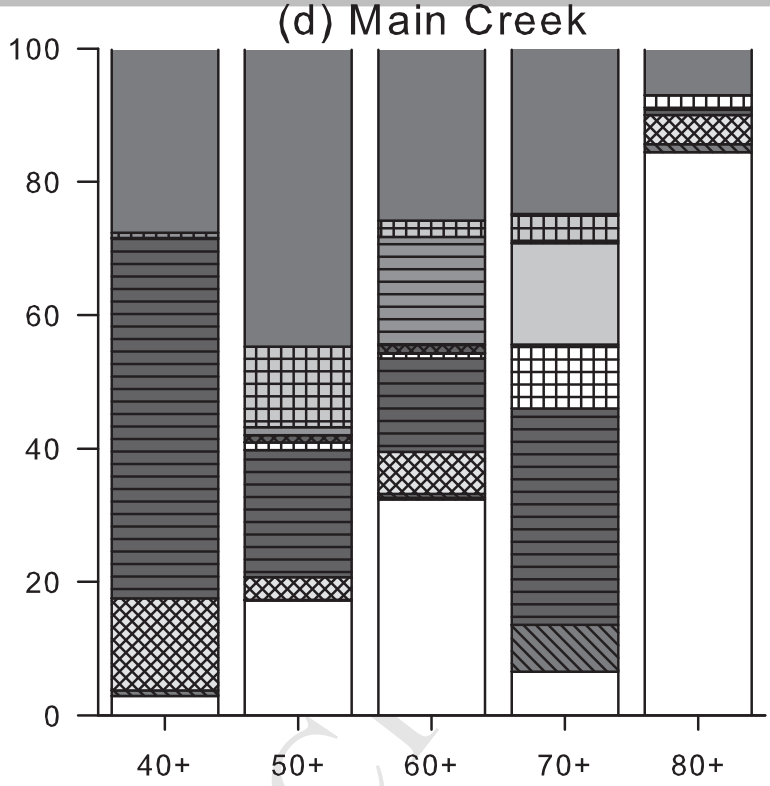

(b) Mill Creek

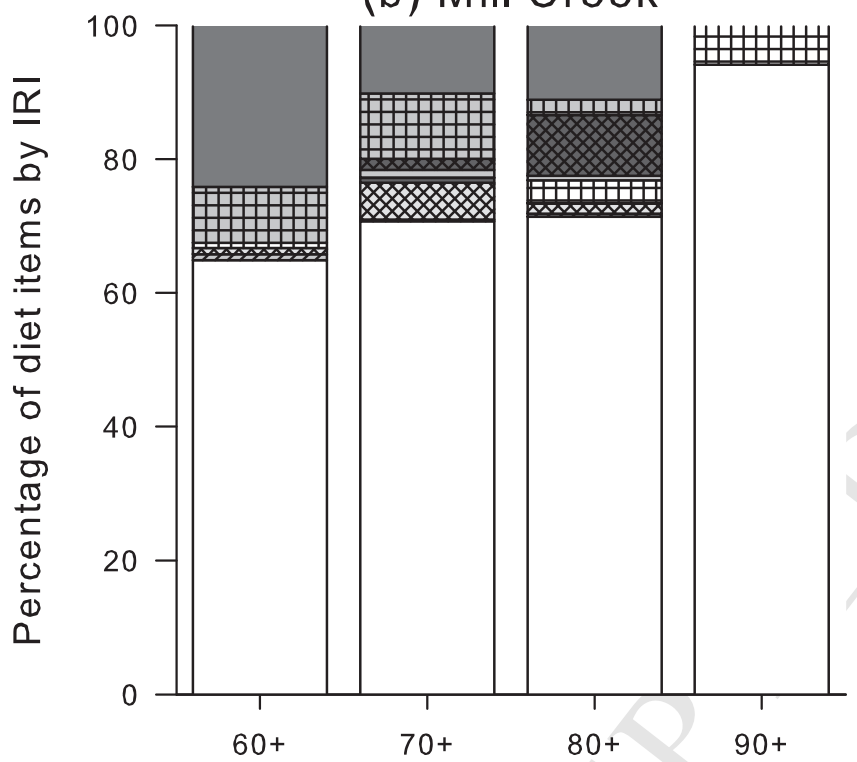

(e) Neck Creek

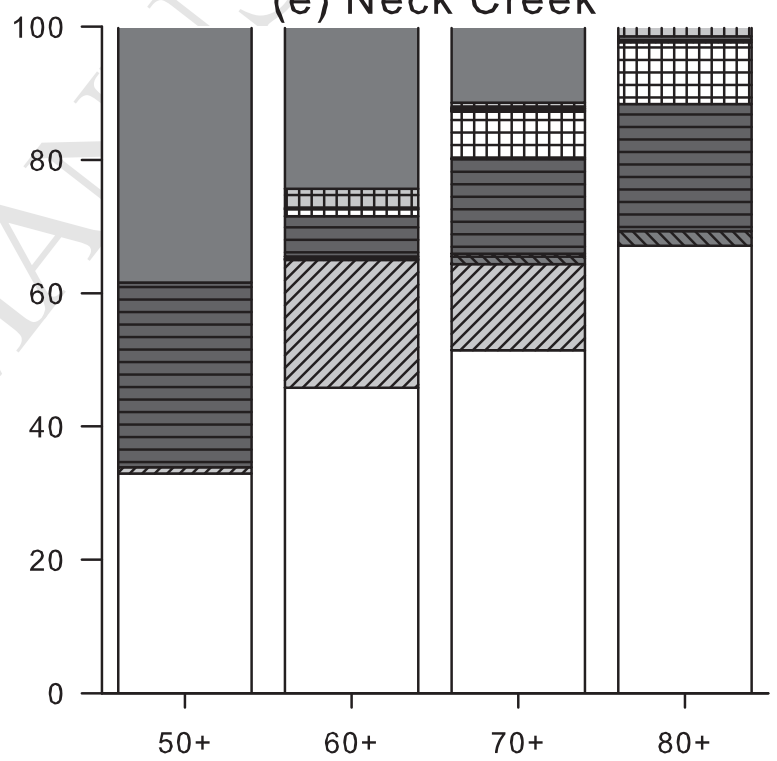

(c) Richmond Creek

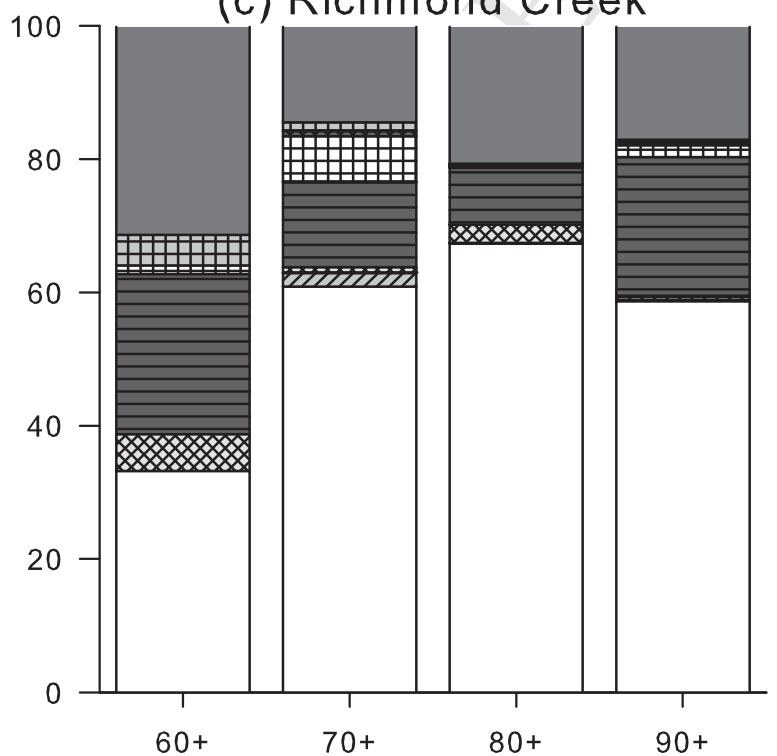

Decapoda

चIIA Amphipoda

MIIV Isopoda

Cirripedia

Polychaeta

피미 Oligochaeta

Nematoda

$\square$ Gastropoda

चIIIA Bivalvia

WIIV Arachnida

Insecta

Zooplankton

Osteichthyes

Alga

$\square$ Detritus

Fish length class ( $\mathrm{mm}, \mathrm{TL})$ 


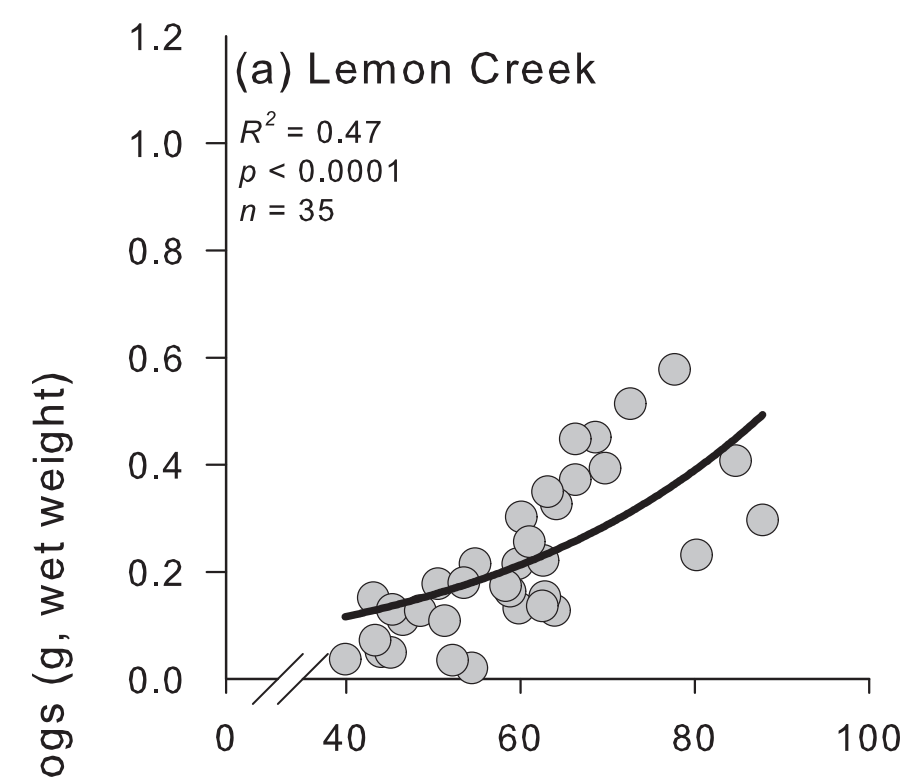

\section{2 (d) Main Creek}

$1.0-R^{2}=0.43$

$p<0.001$

$0.8-n=30$
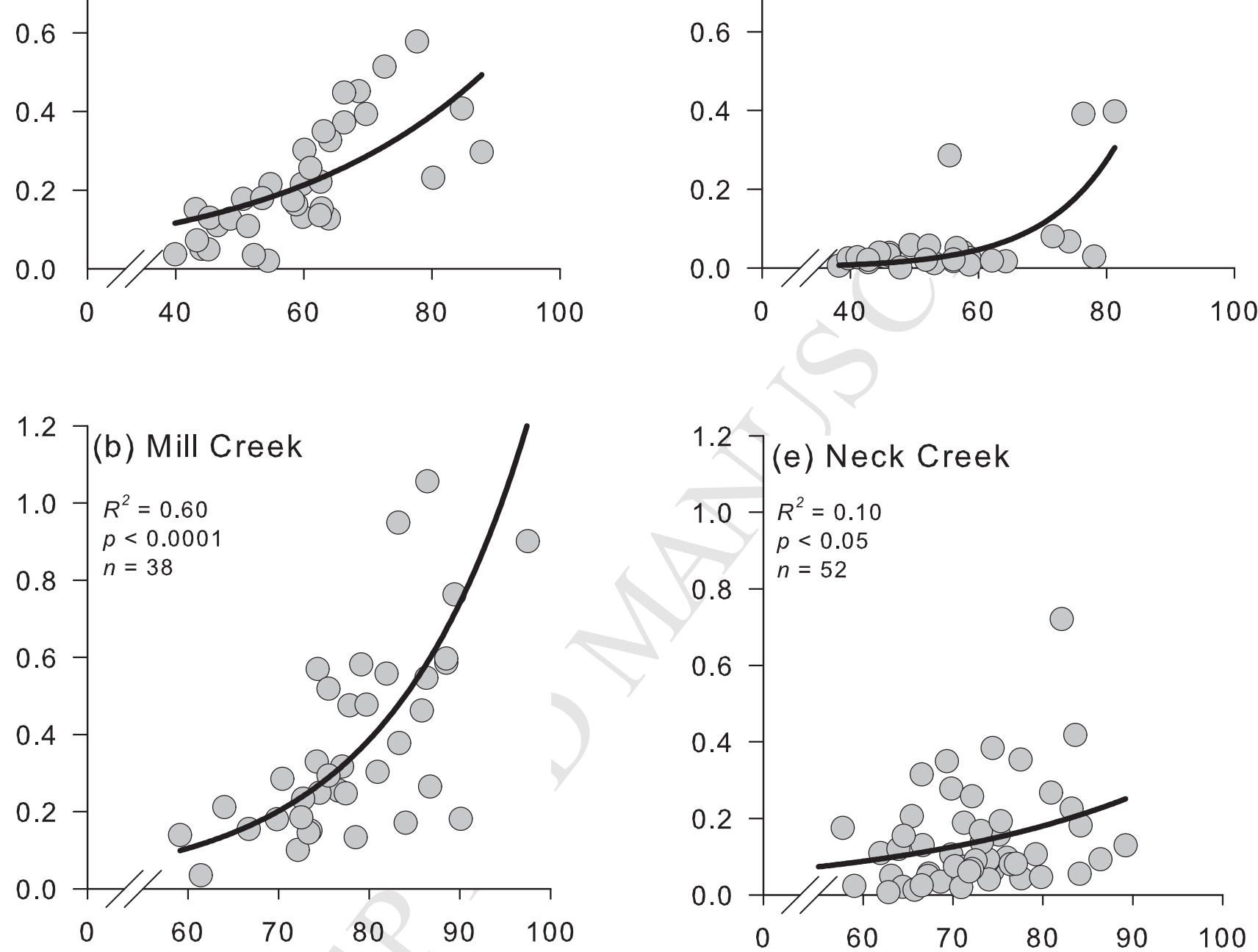

1.27 (e) Neck Creek

$1.0-\begin{aligned} & R^{2}=0.10 \\ & p<0.05\end{aligned}$

$0.8-n=52$
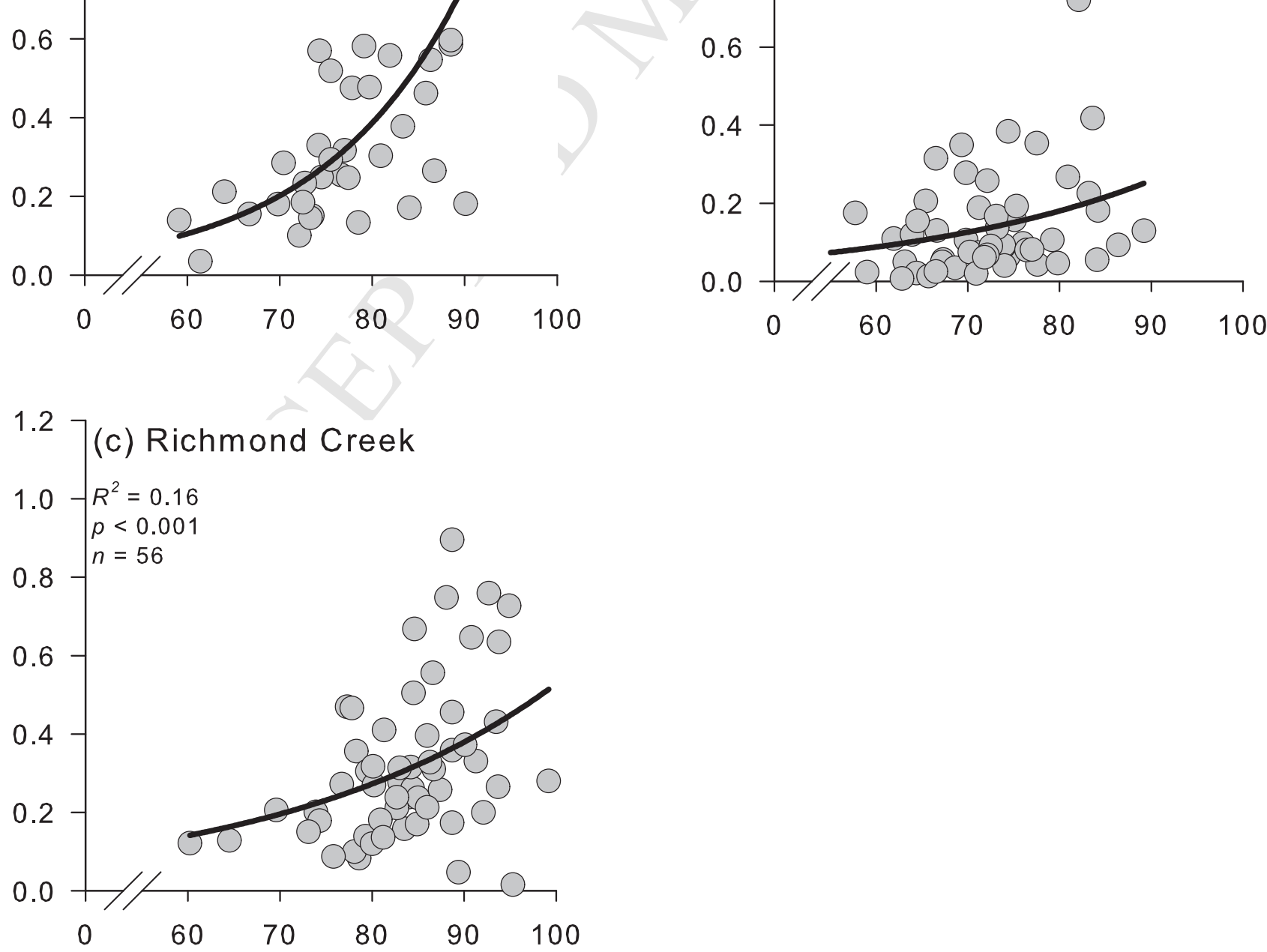

Total length of mummichogs $(\mathrm{mm})$ 


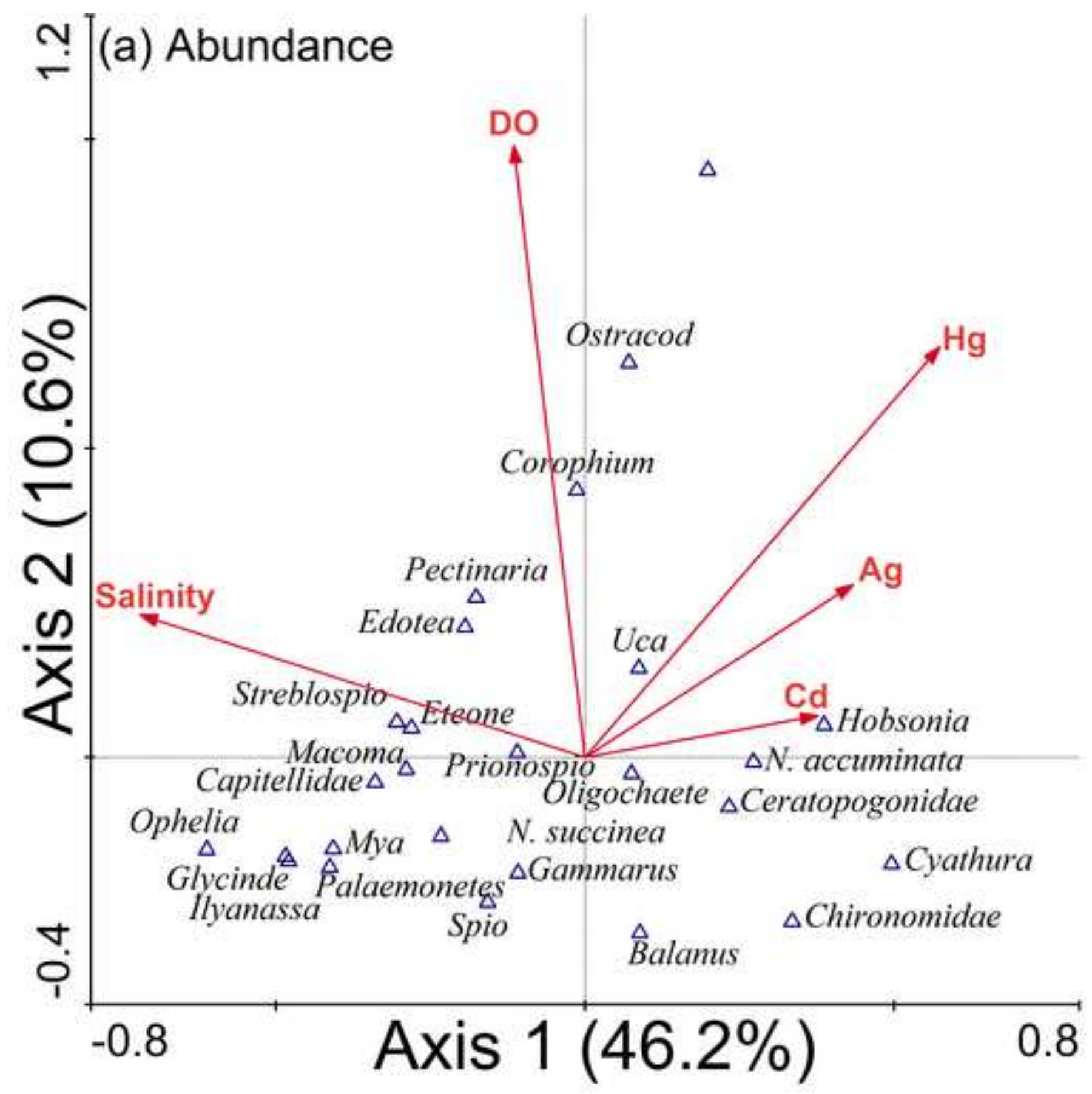




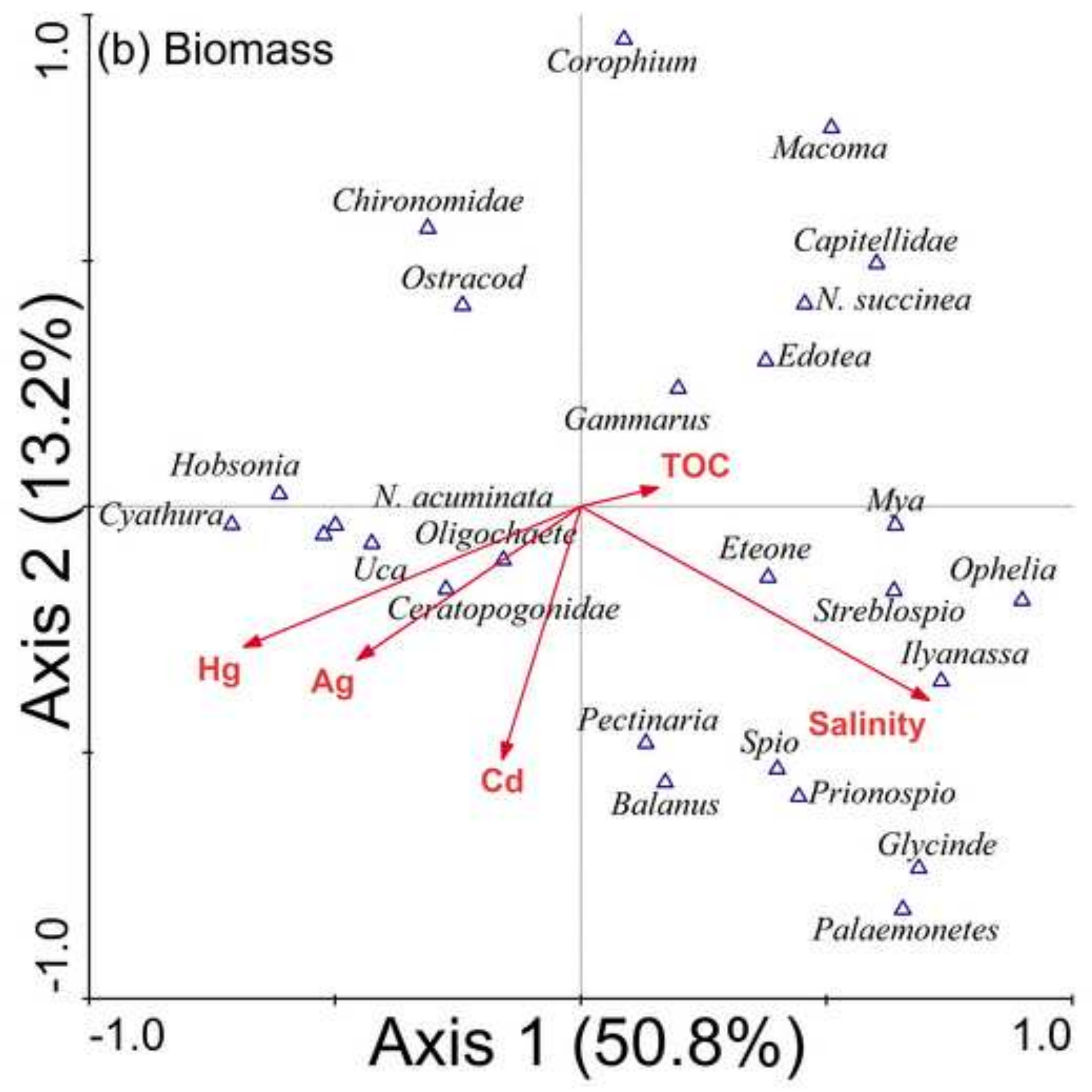




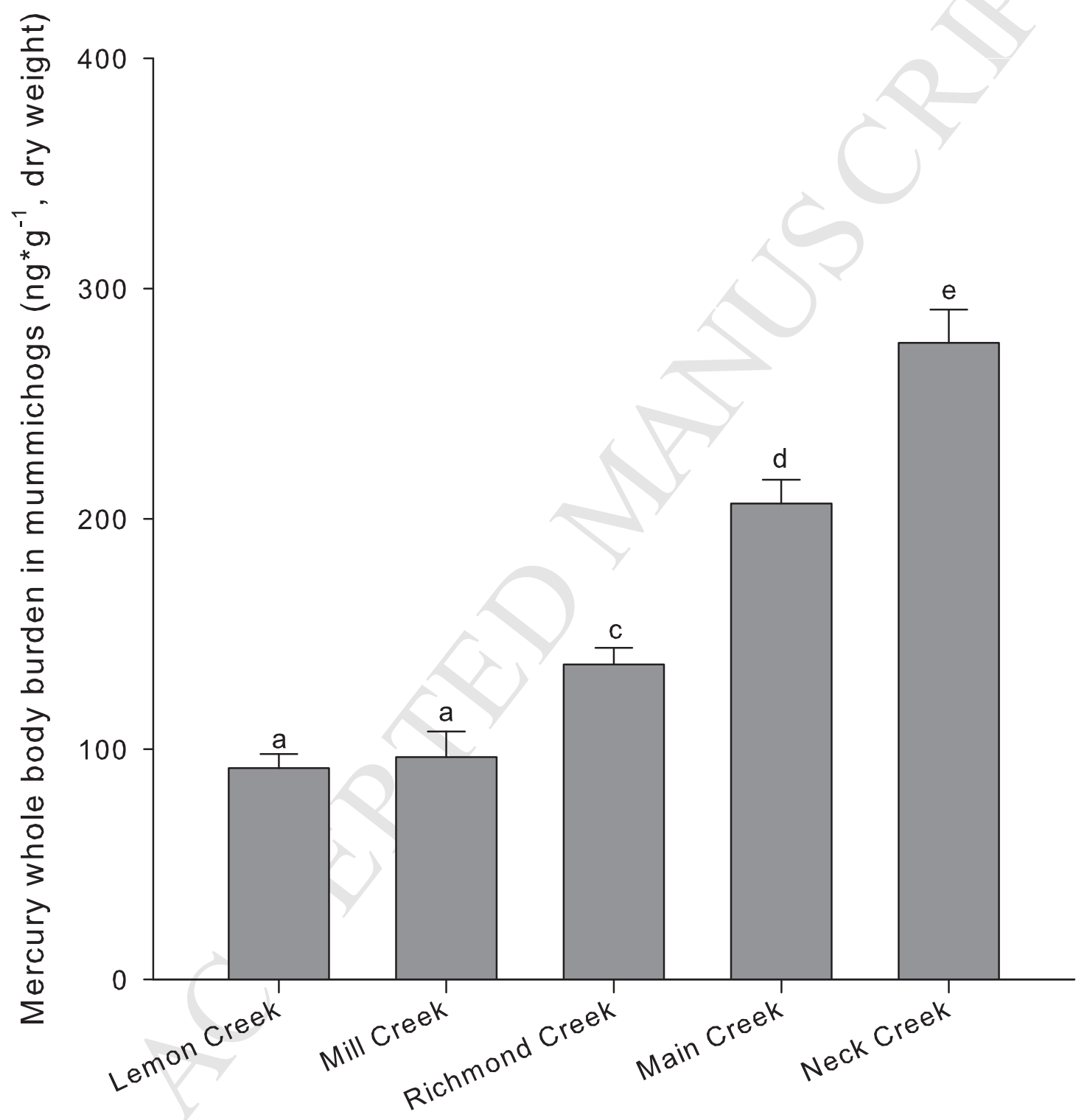




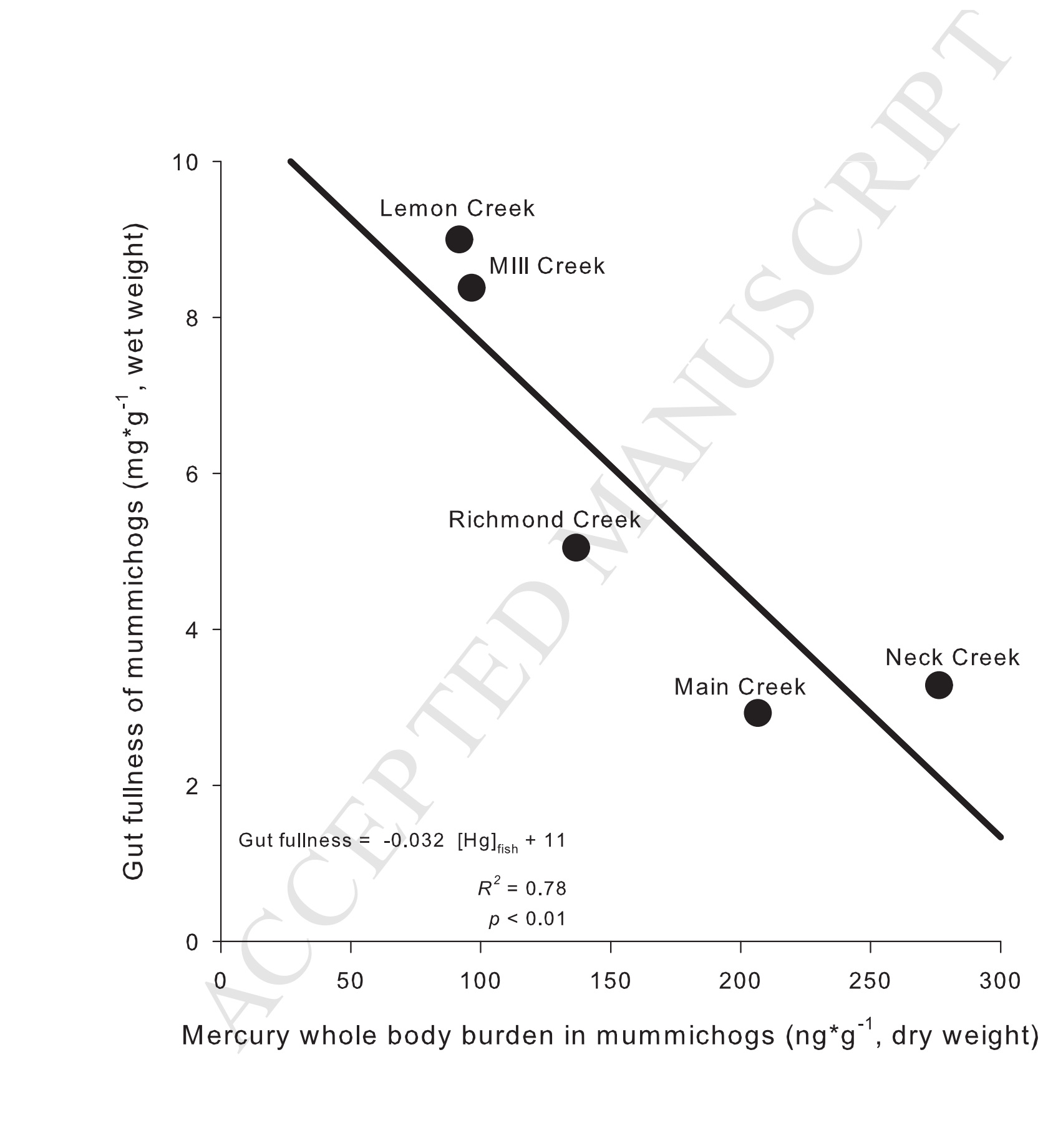

Figure 7
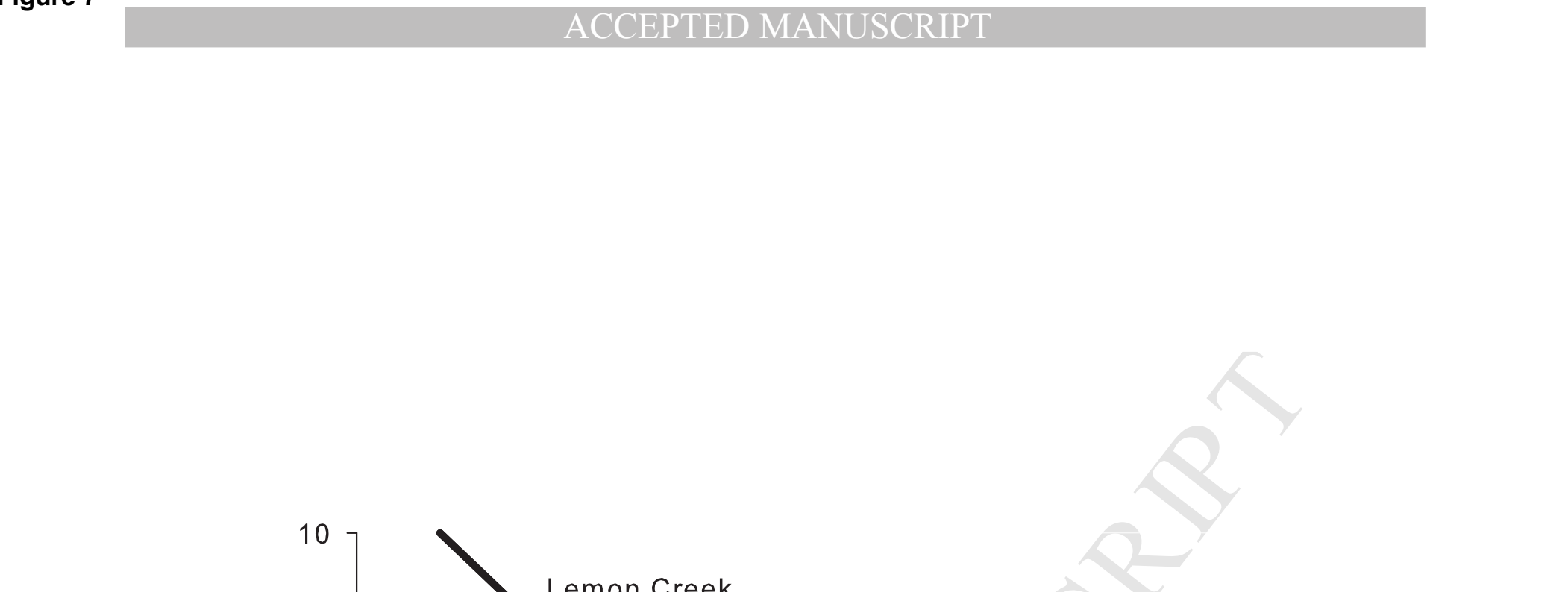

)

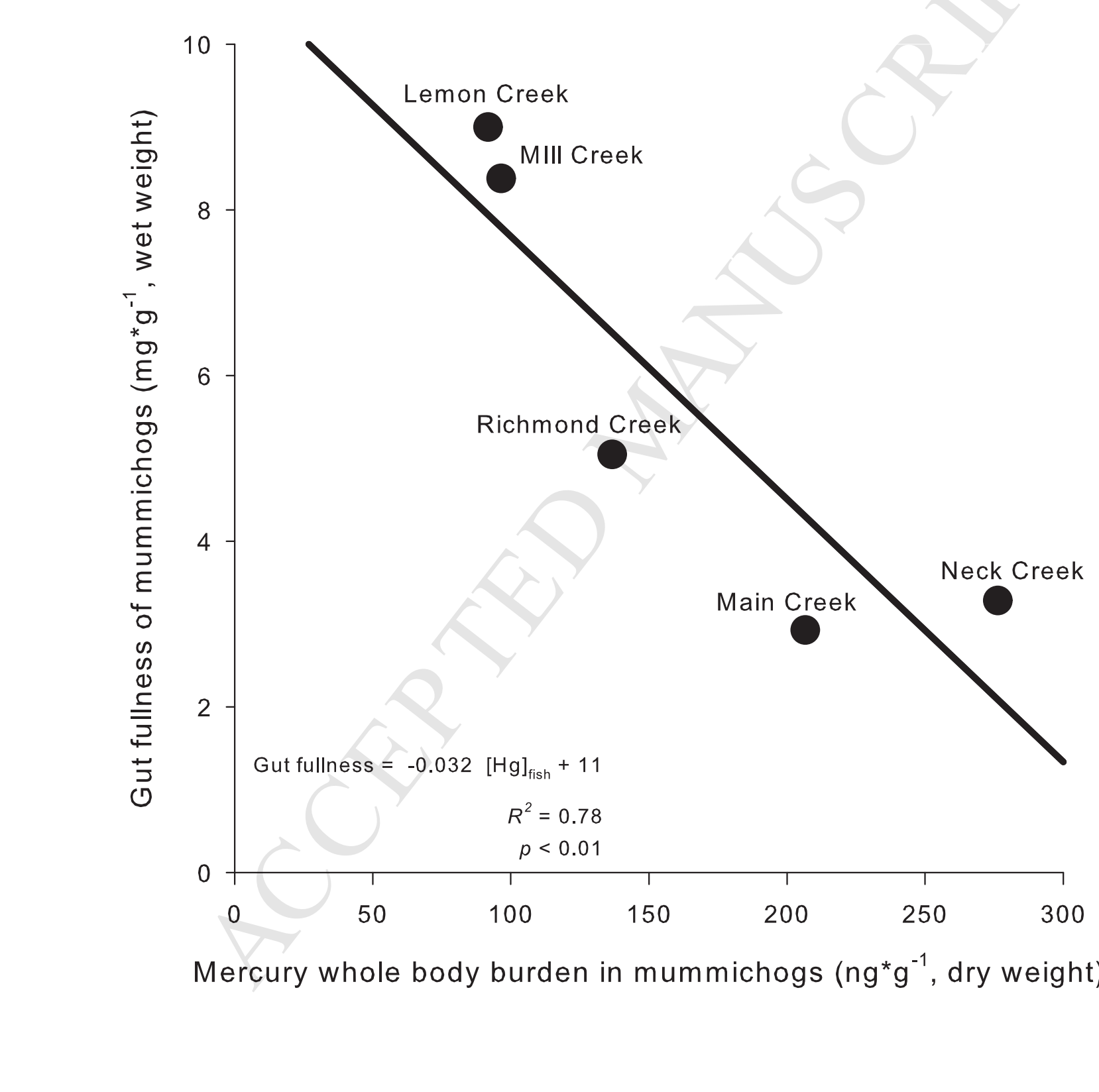

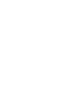
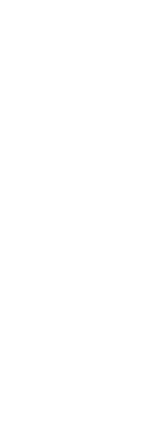